\title{
Morguninn eftir Ponzi
}

\author{
Gylfi Magnússon ${ }^{1}$
}

\begin{abstract}
Ágrip
Pessi grein fjallar um áhrif uppgangs íslenska útrásarhagkerfisins og hruns fjármálakerfisins í kjölfarið á ýmsa eignamarkaði og eigna- og tekjuskiptingu í landinu. Dregið er fram að áhrifin af eignaverðsbólunni eru um margt svipuð og í Ponzi-leik par sem hreinn hagnaður rennur til peirra sem byrja snemma og hætta snemma en aðrir tapa. Vegna pess hve stór hluti hagkerfisins var fjármagnaður með erlendu lánsfé lendir stærstur hluti tapsins á endanum á erlendum lánardrottnum en innlendir aðilar, p. á m. hið opinbera koma að meðaltali furðuvel út. Meðaltölin segja pó ekki alla söguna pví að einstakir hópar innlendra aðila koma afar illa út.
\end{abstract}

\begin{abstract}
This paper analyses the effects of the rise of the Icelandic bubble economy and the subsequent collapse of the financial sector on several asset markets and the domestic wealth and income. It is shown that the effects of the asset price bubble are in many ways similar to those of a Ponzi scheme, where net profits accrue to those that enter and exit early but others lose. Since the Icelandic economy was to a large extent financed by foreign creditors they end up with the bulk of the losses but domestic parties, including the government, escape on average surprisingly well. Such averages do however not tell the whole story since several segments of Icelandic society sustain heavy losses.
\end{abstract}

JEL flokkun: G01;G28;H6

Lykilhugtök: Fjármálakrísa, Ponzi

1 Höfundur er dósent í viðskiptafræðideild Háskóla Íslands og fyrrverandi efnahags- og viðskiptaráðherra. 


\section{$1 \quad$ Inngangur}

Ponzi-leikir eru nefndir eftir Charles Ponzi (1882-1949). Hann vann pað sér til frægðar að reka í upphafi priðja áratugs tuttugustu aldar fjárfestingasjóð í Boston sem póttist geta skilað 100\% ávöxtun á 90 dögum með viðskiptum milli landa með svokölluð alpjóðasvarmerki (international postal reply coupon). Pví fór fjarri að petta væri hægt en Ponzi gat greitt peim sem skiptu fyrst við hann með pví fé sem peir sem síðar komu greiddu honum og pannig haldið svindlinu gangandi um skeið. Раð var pó ekki hægt að gera að eilífu enda hefði fjárfestum purft að fjölga út í hið óendanlega. Fyrirtæki Ponzi hrundi eftir nokkra mánuði og hann endaði í fangelsi. Síðan hafa ýmsar vafasamar viðskiptahugmyndir verið kenndar við Ponzi eða pýramída ef pær eiga pað sameiginlegt að búin er til gerviávöxtun fyrir fé peirra sem fyrstir koma með pví að nýta framlag peirra sem síðar koma og pannig koll af kolli.

Uppgangur útrásar- eða bóluhagkerfisins íslenska og hrun fjármálakerfisins í kjölfarið hefur mörg skýr einkenni Ponzi-leiks. Í pessari grein verða pessi einkenni dregin fram. Sérstaklega verður skoðað hvernig hagkerfið í heild kemur út úr pessum sviptingum og hvaða áhrif pær hafa á eigna- og tekjuskiptingu í landinu. Greinin er að nokkru byggð á ávarpi sem höfundur flutti sem efnahags- og viðskiptaráðherra pann 10. júní 2010 í Háskóla Íslands og fyrirlestri sem haldinn var pann 25. mars 2010 á sama stað.

\section{Ponzi kemur og fer}

Sviptingar í íslensku efnahagslífi undanfarin ár eiga sér fá, ef nokkur, fordæmi. Aðdragandinn er nú að verða vel pekktur. Gríðarlegt streymi fjár til landsins fyrstu árin eftir árpúsundamótin, fyrir tilstuðlan og milligöngu fjármálafyrirtækja, leiddi til verðbólu á öllum helstu innlendu eignamörkuðum auk pess sem raungengi krónunnar hækkaði verulega. Eftir

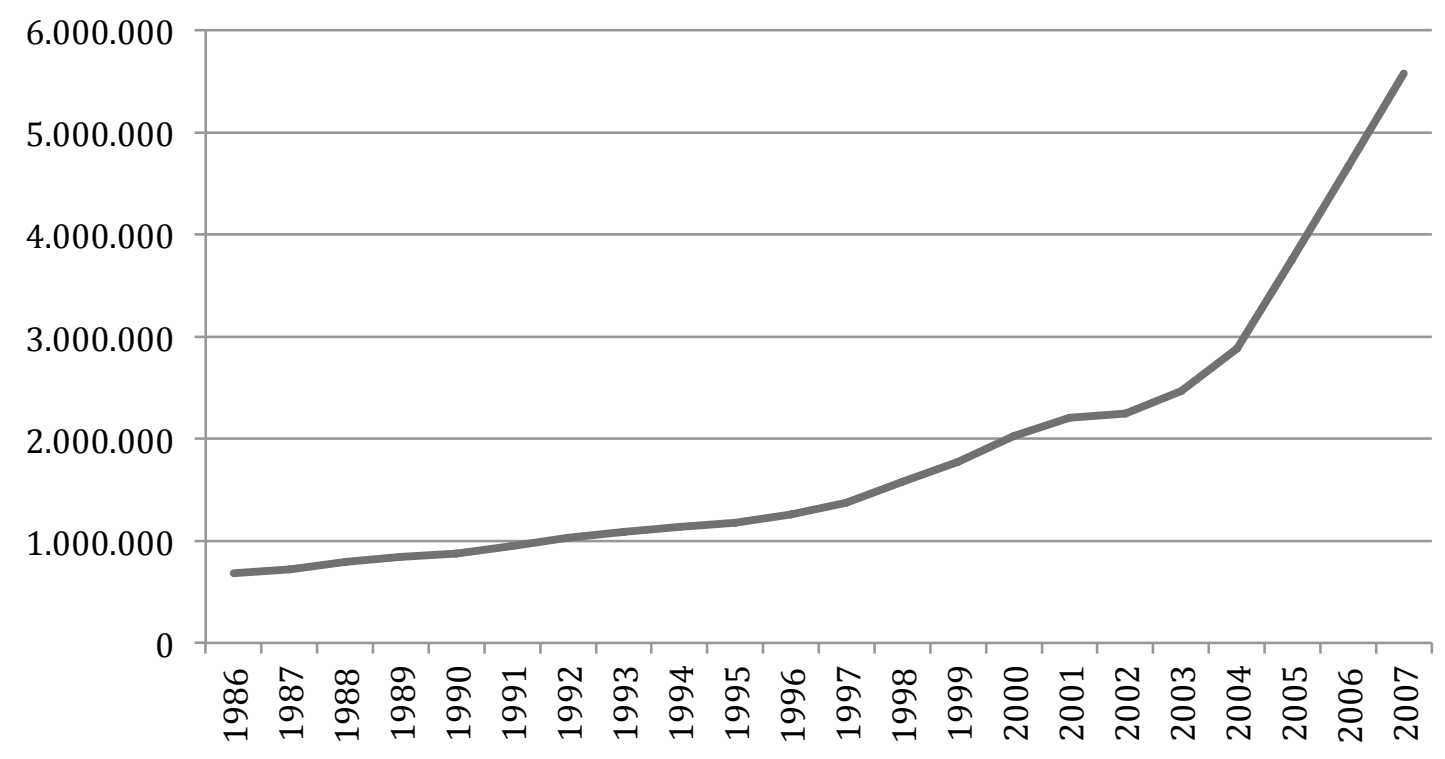

Mynd 1. Innlend útlán og verðbréfaeign íslenska bankakerfisins á verðlagi í árslok 2007 (milljónir króna) 
að hafa vaxið um 7,8\% á ári að raunvirði árlega frá 1986 til 2003 stækkaði bankakerfið um 22,6\% á ári frá 2003 til 2007, sé miðað við samanlögð innlend útlán pess og verðbréfaeign. Sjá nánar mynd 1.

Árið 2006 fóru áhyggjur af stöðugleika íslenska fjármálakerfisins að hafa veruleg áhrif á getu pess til að soga til sín fjármagn pótt nýjar leiðir, sérstaklega netinnlánsreikningar í nokkrum Evrópulöndum, væru reyndar. Árið eftir, um mitt ár 2007, náði bólan hámarki.

Í kjölfarið hjaðnaði bólan hratt. Hlutabréfaverð, fasteignaverð og gengi krónunnar snarféll í lækkunarhrinu sem stóð yfir í rúmt ár. Viðskiptavinir og eigendur fjármálafyrirtækja komust hver á fætur öðrum í vandræði pegar eigið fé sem hafði verið til á pappír gufaði upp vegna hjöðnunar eignaverðsbólunnar. Sífellt meiri skortur varð á lánsfé, sérstaklega í erlendri mynt. Loks hrundi bankakerfið í október 2008 pegar erlent lausafé var uppurið. Lokakaflinn í sögu bóluhagkerfisins íslenska er um margt svipaður og pegar Ponzileikur hrynur. Pegar trú manna á kerfið pverr hættir nýtt fé að streyma inn í pað. Peir sem fyrir eru reyna að ná fé sínu út án árangurs og kerfið hrynur.

Pessi saga verður ekki rakin hér enda hefur pað pegar verið ágætlega gert annars staðar, sérstaklega í skýrslu Rannsóknarnefndar Alpingis (RNA). Hins vegar verða dregnar fram nokkrar afleiðingar pessarar atburðarásar, m.a. fyrir langtímaávöxtun á nokkrum eignamörkuðum sem hafa áhrif á eigna- og tekjuskiptingu í landinu. Pá verður sérstaklega reynt að draga upp framtíðarsýn fyrir íslenskt atvinnulíf og pjóðarbú í ljósi pess sem gerst hefur.

Eignaverðsbóla sem springur getur haft mikil áhrif á eigna- og tekjuskiptingu. Á uppgangstíma hennar verða margir ríkir, a.m.k. á pappír, og að sama skapi tapa margir miklu pegar hún hjaðnar eða springur. Ferlið er vitaskuld ekki svo snyrtilegt að peir sem hagnast á uppganginum tapi pví síðan einfaldlega aftur og allir séu eins staddir og áður pegar upp er staðið. Hluti peirra sem hagnast á uppgangstímanum tapar að vísu öllu aftur. Aðrir ná að byggja upp auð og halda honum og enn aðrir enda með minna en peir áttu í upphafi. Petta er um margt svipað og í pýramídasvindli eða Ponzi-leik. Peir sem hefja leik snemma og hætta snemma koma alla jafna vel út en peir sem byrja seint og hætta seint koma undantekningalítið illa út. Рað á við um alla pá markaði sem hér verða skoðaðir, hlutabréfamarkaðinn, fasteignamarkaðinn og markaðinn fyrir íslensku krónuna (eða erlent lánsfé).

\subsection{Hlutabréfamarkaður}

Hlutabréfamarkaðurinn íslenski hækkaði mest allra innlendra eignamarkaða í aðdraganda hrunsins. Meðalraunávöxtun, án arðs, á ári var rétt um 18,2\% frá árinu 1986 til ársloka 2007. Раð pýðir að raunvirði hlutafjár meira en prítugfaldaðist á pessum tíma. ${ }^{2}$ Sé tekið tillit til arðs hækkar mæld árleg raunávöxtun um u.p.b. 2 prósentustig til viðbótar. ${ }^{3}$ Pegar vöxtur bankanna og útlána peirra var hvað mestur, árin 2003 til 2005, var raunávöxtun íslenska hlutabréfamarkaðarins meira en $50 \%$ á hverju ári, prjú ár í röð. Sjá nánar mynd 2. Hlutabréfamarkaðurinn náði hámarki í júlí 2007. Pá tók verð að lækka mjög skarpt, prátt fyrir umsvifamiklar tilraunir fjármálafyrirtækja til að halda pví uppi með eigin viðskiptum og lánum til hlutabréfakaupa, sem lýst er ágætlega í skýrslu RNA.

\footnotetext{
${ }^{2}$ Miðað er við svokallaða HMARK vísitölu fyrir árin 1986 til 1992 en ICEX-15 (Úrvalsvísitala) eftir pað. Pess má geta að nafnverðið meira en hundraðfaldaðist frá 1986 til 2007.

3 Tölur um ávöxtun vegna arðs fyrstu ár markaðarins liggja ekki fyrir en hér er miðað við tölur frá og með árinu 1993.
} 


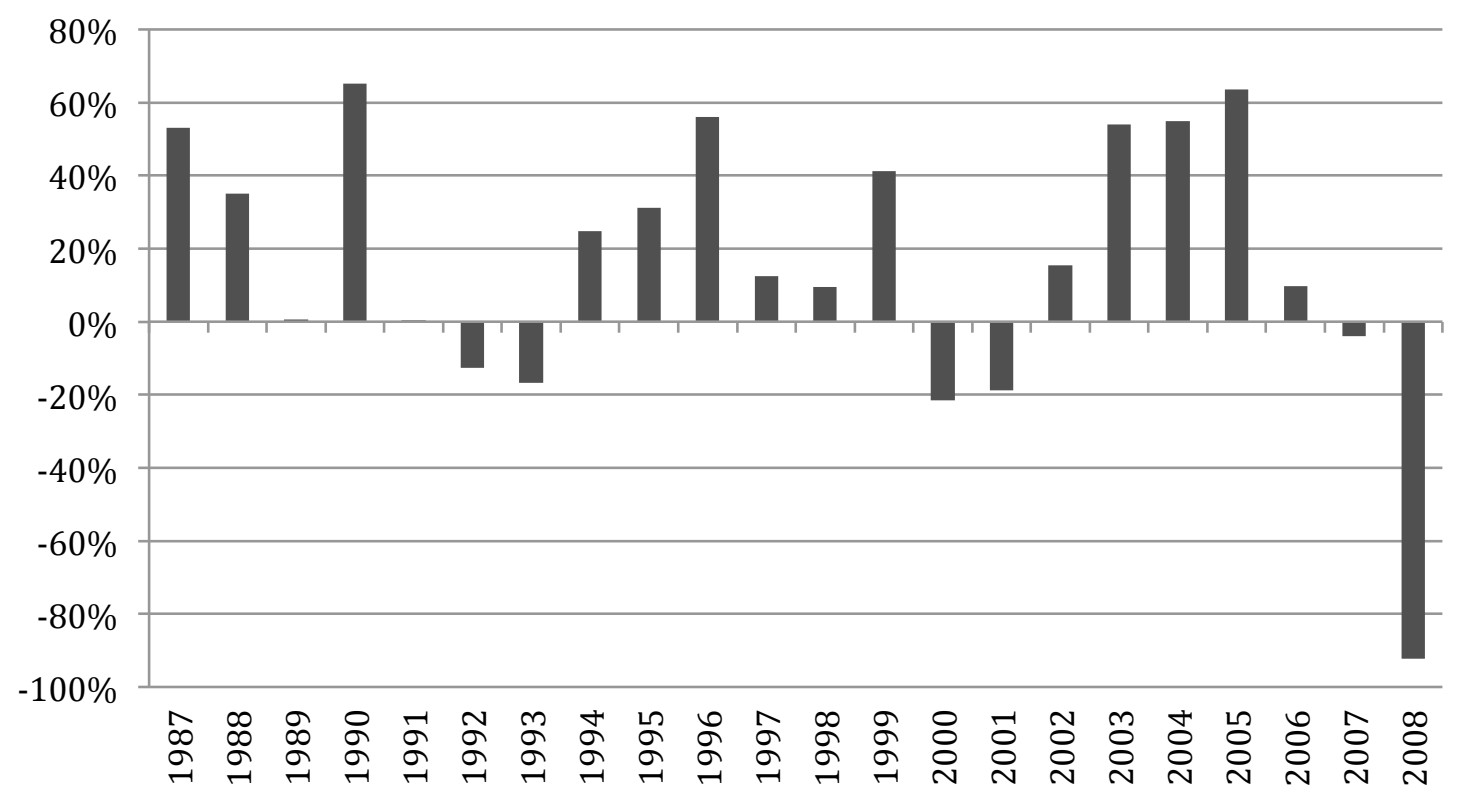

Mynd 2. Raunávöxtun hlutabréfa frá 1987 til 2008 m.v. vísitölu neysluverðs án húsnæðis (án arðs) Heimild: Kauphöll Íslands, HMARK og útreikningar höfundar.

Loks lokaði hlutabréfamarkaðurinn alveg vegna óvissu, sérstaklega um stöðu fjármálafyrirtækja, í október 2008. Pegar viðskipti hófust að nýju eftir hrun bankakerfisins um miðjan október 2008 höfðu um 94\% af markaðsvirði hans horfið á 15 mánuðum. Pegar markaðurinn náði lágmarki í apríl árið á eftir höfðu samtals 96,7\% af markaðsvirði að raunvirði horfið frá pví pað náði hámarki í júlí 2007. Hrun hlutabréfamarkaðarins árið 2008 pýðir vitaskuld að söguleg meðalávöxtun íslenska hlutabréfamarkaðarins er orðin miklu lægri en hún mældist árið 2007. Langtímaraunávöxtunin er pó ekki verri en svo að hún mælist 4,4\% frá árslokum 1986 til ársloka 2008, án arðs, og um pað bil 6,4\% á ári með arði. Sjá nánar mynd 3.

Á bólutímanum var algengt að tekin væri voguð staða í hlutabréfum, p.e. pau fjármögnuð að hluta með lánsfé. Í sumum tilfellum voru lánin í erlendri mynt og áhættan pví tvípætt, annars vegar vegna verðbreytinga á hlutabréfum í innlendri mynt og hins vegar vegna breytinga á gengi krónunnar gagnvart viðkomandi erlendum myntum.

Með pessum hætti var hægt að margfalda áhrif uppsveiflunnar á verði hlutabréfa. Sem dæmi má nefna ímyndaðan einstakling sem keypti hlutabréf í ársbyrjun 2002 fyrir eina milljón króna og fjármagnaði kaupin með 30\% eigin fé og 70\% lánsfé í krónum á REIBOR vöxtum. Pessi einstaklingur nýtti sér síðan vöxt eigin fjár á pappír vegna verðhækkunar hlutabréfa til að auka við hlutabréfasafn sitt einu sinni á ári með frekari lántöku pannig að eiginfjárhlutfallið varð aftur $30 \%$.

Í upphafi ársins 2008 hefði upphaflega milljónin verið orðin á sex árum að rétt um 1,6 milljörðum króna, á sama verðlagi. ${ }^{4}$ Hefði fjárfestirinn tekið lán í erlendri mynt á LIBOR vöxtum hefði ávöxtunin getað orðið enn ævintýralegri. T.d. hefði eigið fé vaxið í 3,1 milljarð ef lán hefði verið tekið í evrum og 5,1 milljarð m.v. lán í japönskum jenum. Pað er pví ekkert skrýtið að til varð fjöldi milljarðamæringa á pessum tíma. Раð purfti enga hæfileika til, hvað

\footnotetext{
${ }^{4}$ Hér er ekki tekið tillit til fjármagnstekjuskatts eða annars kostnaðar eða pess ef fjárfestirinn parf að greiða álag ofan á REIBOR vexti. Á móti kemur að ekki er tekið tillit til arðgreiðslna.
} 


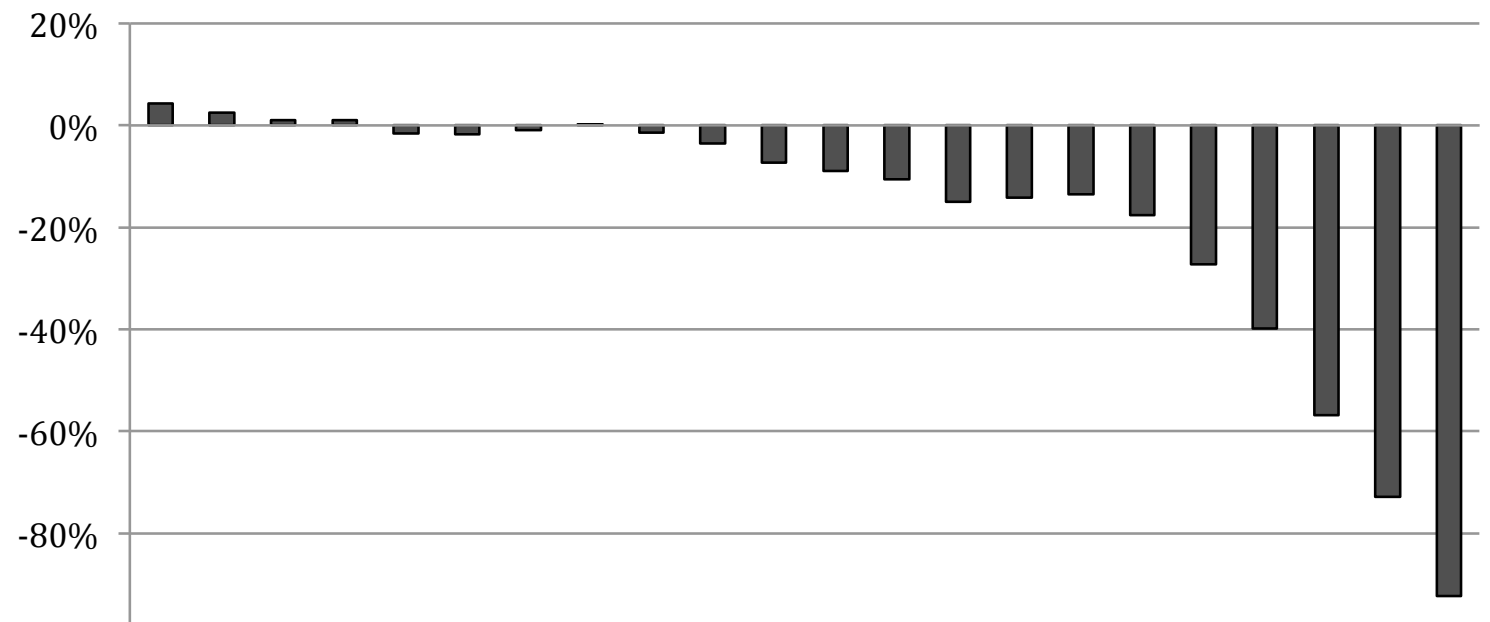

Mynd 3. Árleg meðalraunávöxtun hlutabréfa til ársloka 2008

m.v. mismunandi kaupdag (án arðs)

Heimild: Kauphöll Íslands, HMARK og útreikningar höfundar.

pá snilligáfu, bara heppni með tímasetningu, greiðan aðgang að lánsfé og áhættusækni. ${ }^{5}$

Árið 2008 snerist gæfan við og peir sem voru með vogaða stöðu í hlutabréfum töpuðu undantekningalítið öllu eigin fé sínu og gott betur ef peir seldu ekki bréfin tímanlega. Sá sem fjármagnaði hlutabréfakaup sín í krónum m.v. fyrrgreindar forsendur hefði pá í árslok skuldað 3,6 milljarða umfram eignir og sá sem gerði pað í jenum hefði skuldað 8,4 milljarða umfram eignir.

Í lækkunarhrinunni dugðu veðköll skammt til að verja hagsmuni lánveitenda. Kaupendur hlutabréfa fundust ekki nema peir væru búnir til með lánveitingum. Pað pýddi að peir sem lánað höfðu til hlutafjárkaupa gátu ekki losnað við áhættuna af frekara falli hlutabréfaverðs. Peir gátu bara fært hana af einu útláni til annars. Pegar hjörðin öll ætlar að troða sér út um neyðarútganginn á sama tíma kemst enginn neitt. Рað átti við á flestum íslensku eignamörkuðunum, með hlutabréf, skuldabréf fyrirtækja, fasteignir og krónuna.

\subsection{Fasteignir}

Raunverð fasteigna hækkaði um 60\% frá ársbyrjun 1998 til miðs árs 2004 eftir stöðnun mestallan tíunda áratuginn. ${ }^{6}$ Рað stóð pó nokkurn veginn í stað 2001 og 2002. Um mitt ár 2004 tók verðið að hækka enn hraðar og hækkaði um 45\% á um tveimur og hálfu ári. Skýring pess er augljós en á síðari hluta ársins 2004 hófu bankar og sparisjóðir að veita einstaklingum lán til fasteignakaupa í stórum stíl, bæði í krónum og í erlendri mynt eða með gengistryggingu. Pá rýmkaði Íbúðalánasjóður einnig útlánareglur sínar á pessu tímabili. Hagvöxtur

${ }^{5}$ Pess má geta að sá sem hefði byrjað með sömu fjárfestingarstefnu tveimur árum áður, í ársbyrjun 1999, hefði klárað allt eigið fé sitt á árinu 2001, hvort sem hann hefði fjármagnað kaupin í krónum eða algengustu erlendu myntum. Árin 2000 og 2001 fór saman veiking krónunnar og lækkun hlutabréfaverðs, líkt og árið 2008, pótt sviptingarnar væru minni. Áhættan við pessi viðskipti hefði pví átt að blasa við bæði lántakendum og lánveitendum. Рað purfti ekki að fara langt aftur í tímann til að sjá pað.

6 Stöðnun fasteignaverðs framan af tíunda áratugnum á sér væntanlega fyrst og fremst pá skýringu að mjög illa áraði í efnahagslífinu. Pannig voru bæði landsframleiðsla og pjóðartekjur á mann lægri árið 1996 að raunvirði en pær höfðu verið 1987. Atvinnuleysi var einnig óvenjumikið framan af tíunda áratugnum. 


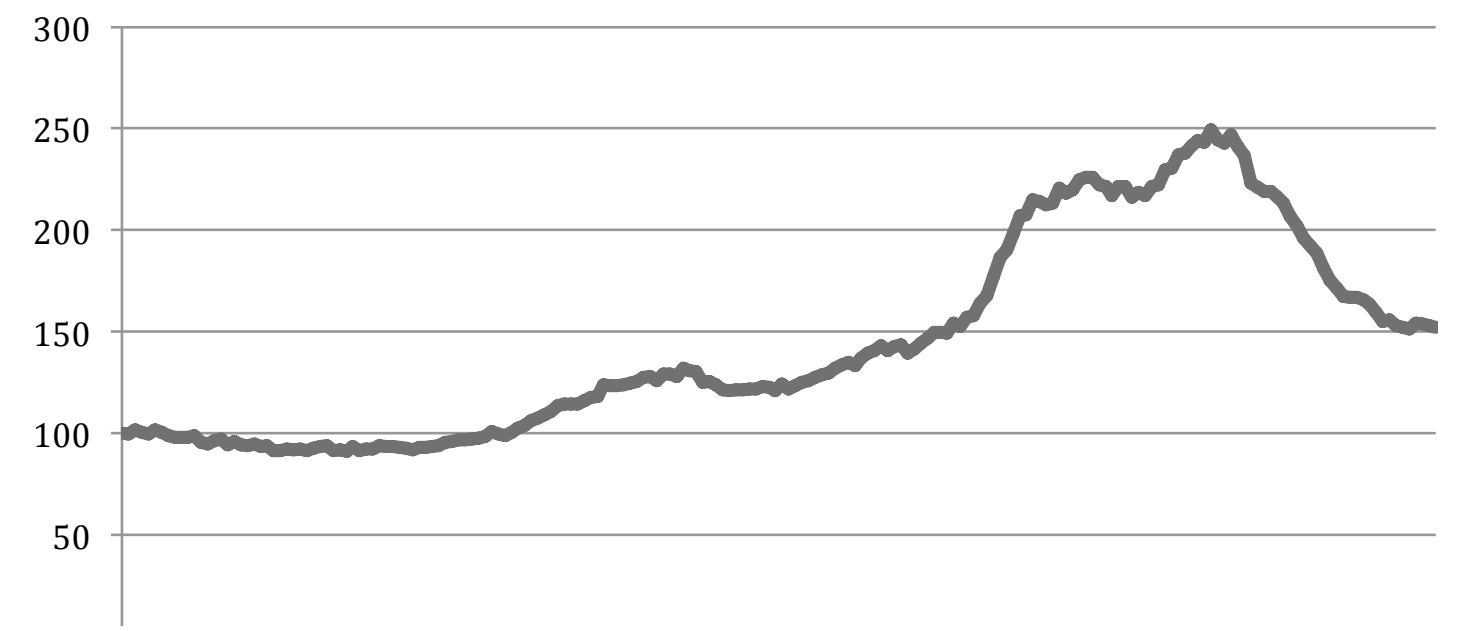

Mynd 4. Raunverð fasteigna á höfuðborgarsvæðinu m.v. vísitölu neysluverðs án húsnæðis 1994-2010 (vísitala í janúar $1994=100$ )

Heimild: Pjóðskrá Íslands, Hagstofan og útreikningar höfundar.

mældist mjög mikill árin 2004 (6,9\%) og 2005 (6,4\%) og ráðstöfunartekjur jukust að sama skapi. Eignaverðsbólan pandist út með mestum hraða á pessum tíma, p.e. árin 2004 til 2006. Undir lok ársins 2006 hægði aftur mjög á hækkun fasteignaverðs. •að náði pó ekki hámarki fyrr en síðla árs 2007 og hafði pá hækkað um 167\% á tæpum 9 árum eða að jafnaði um 10,5\% á ári að raunvirði. ${ }^{7}$ Sjá nánar mynd 4.

Líkt og á hlutabréfamarkaðinum skipta tímasetningar kaupa og sölu höfuðmáli á fasteignamarkaðinum. Sá sem hefði keypt 10 milljón króna fasteign í ársbyrjun 1998 og selt hana pegar markaðurinn náði hámarki í október 2007 hefði fengið samanlagt 166\% raunávöxtun á eignina. Er pá ekki tekið tillit til afnota viðkomandi af íbúðinni eða leigutekna.

Hefði fasteignakaupandinn byrjað með 3 milljónir í eigið fé en tekið 7 milljónir að láni í krónum á REIBOR vöxtum hefði hann endað með 15 milljónir í eigið fé, á föstu verðlagi m.v. vísitölu neysluverðs án húsnæðis. Hann hefði fengið um 18\% meðalraunávöxtun á ári á sitt fé, auk afnota af húsinu. Petta er gríðarleg aukning á eigin fé á pappír. Verðmiði hússins breyttist pótt húsið gerði pað ekki. Líkt og á hlutabréfamarkaðinum var hægt að nýta petta eigið fé sem til varð á pappír til ýmissa hluta, t.d. taka aukin lán út á eignina eða selja hana og innleysa par með hagnað.

Hefði fyrrnefndur fasteignakaupandi ekki selt í október 2007 heldur í ágúst 2010, pegar markaðurinn hafði aftur lækkað verulega, hefði hann engu að síður fengið pví sem næst allt eigið fé sitt að raunvirði til baka við söluna. Afnot hans af íbúðinni hefðu pví verið honum afar ódýr.

Sá sem hefði hins vegar keypt pegar markaðurinn var í hámarki árið 2007 hefði í ágúst 2010 verið búinn að tapa öllu eigin fé sínu og gott betur. Hann myndi pá skulda um 1,1 milljón umfram markaðsverð íbúðarinnar, sem væri komið í rétt rúmar 6 milljónir, allt á föstu verðlagi. Petta er m.v. lán í krónum, hefði hann tekið lán í erlendri mynt fyrir kaupunum væri staðan enn verri. Lán í japönskum jenum stæði t.d. í um $215 \%$ af markaðsvirði íbúðarinnar og eigið fé neikvætt um rétt tæpar 7 milljónir.

${ }^{7}$ Miðað er við hækkun vísitölu alls íbúðarverðs á höfuðborgarsvæðinu umfram hækkun vísitölu neysluverðs án húsnæðis. Rétt er að hafa í huga að fasteignaverð hækkaði almennt meira á höfuðborgarsvæðinu en utan pess á pessu tímabili. 


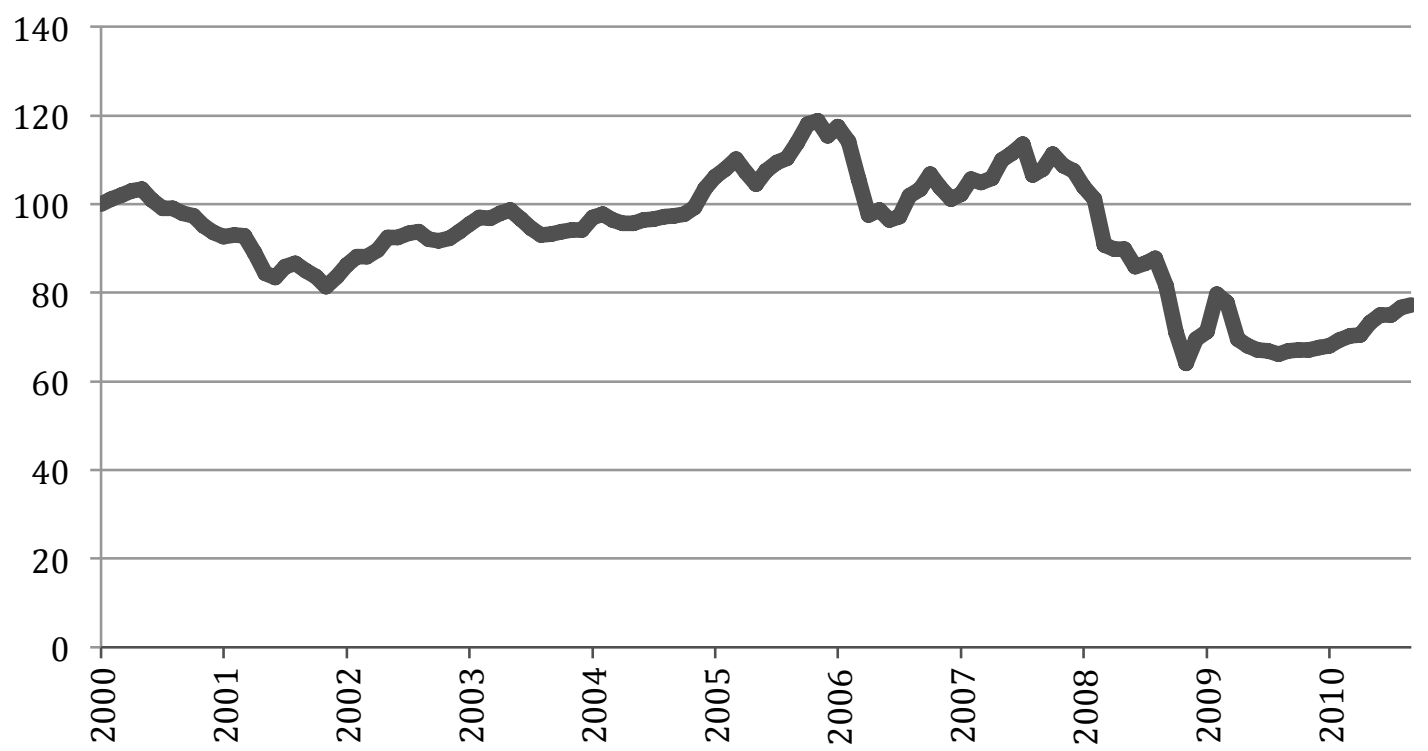

Mynd 5. Raungengi íslensku krónunnar 2000-2010 m.v. neysluverð (vísitala janúar $2000=100$ )

Heimild: Seðlabanki Íslands.

\subsection{Krónan og erlendar myntir}

Raungengi krónunnar féll nokkuð árin 2000 og 2001 vegna umtalsverðs falls nafngengis eftir að Seðlabankinn hætti að reyna að standa á gengisviðmiði sínu í mars árið 2000. Raungengið styrktist síðan verulega aftur næstu fjögur árin. Рað varð hæst síðla árs 2005 og hafði pá hækkað um tæp 50\% á fjórum árum. Pað sveiflaðist síðan talsvert næstu tvö árin uns við tók mikil lækkunarhrina sem hófst haustið 2007. Henni lauk ekki fyrr en bankakerfið hrundi í október 2008 og gjaldeyrishöftum var komið á. Sjá nánar mynd 5.

Hér verður ekki reynt að greina orsakir pessara gengissveiflna pótt pað sé út af fyrir sig mjög áhugavert viðfangsefni. Pó verður að benda á hið einfalda samhengi að pegar mikið erlent fé streymdi til landsins styrktist krónan en pegar streymið hætti og snerist við veiktist krónan. раð er í grundvallaratriðum bara spurning um framboð og eftirspurn.

Hér verður hins vegar skoðað hvernig fjárfesting eða lántaka í erlendri mynt kom út í ljósi sveiflnanna. Sagan er um margt svipuð og á hinum tveimur mörkuðunum sem áður voru skoðaðir. Peir sem tóku lán í erlendri mynt snemma koma vel út, jafnvel pótt peir hafi enn skuldað pegar krónan veiktist hvað mest, en peir sem tóku erlend lán skömmu áður en krónan veiktist koma illa út, a.m.k. ef lánin voru tekin til skamms tíma.

Grundvallarskýringin á mikilli sókn íslenskra aðila í erlent lánsfé er einfaldlega sá munur sem sögulega hefur verið á milli nafn- og raunvaxta í krónum annars vegar og ýmsum erlendum myntum hins vegar. Lántaka í erlendri mynt var nær undantekningalaust mun hagkvæmari á tíunda áratugnum og fyrstu árin eftir aldamótin, allt til ársins 2007. Sem dæmi má nefna að sá sem hefði tekið lán í japönskum jenum með LIBOR vöxtum snemma árs 1999 og greitt pað upp um mitt ár 2007 hefði að jafnaði greitt um -5,1\% raunvexti á ári, mælt í krónum á föstu verðlagi, á tímabilinu og pannig einungis purft að endurgreiða um tvo priðju hluta upphaflegs höfuðstóls að raunvirði. Hefði lánið verið í dollurum hefðu raunvextirnir verið aðeins hærri, eða $-1,1 \%$ og í evrum $0,3 \%$. Á pessu tímabili vann saman vaxtamunur og styrking raungengis krónunnar.

Áhættan var pó talsverð eins og sjá mátti árin 2000 og 2001 pegar bæði nafn- og 


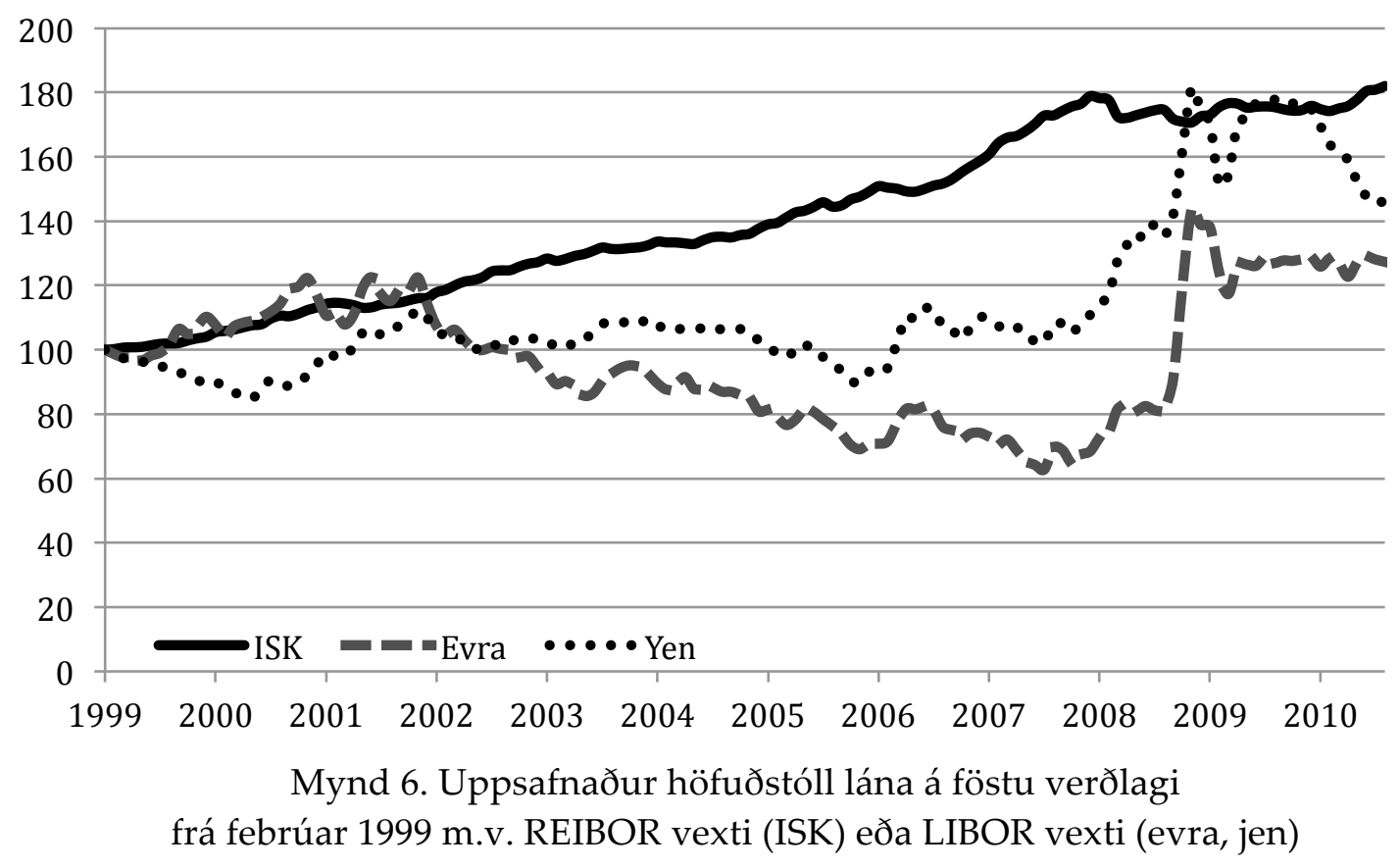

raungengi krónunnar féll töluvert eða um rétt rúman fimmtung á einu og hálfu ári. Pað kom mörgum íslenskum fyrirtækjum sem pá skulduðu í erlendri mynt í mikinn vanda um skeið. Рað sýndi vel hve áhættusöm stöðutaka í erlendri mynt var fyrir pá sem hvorki höfðu tekjur né eignir í erlendri mynt á móti. Sú reynsla virtist pó að mestu gleymd skömmu síðar en gengisfall áranna 2000 og 2001 gekk til baka og gott betur árin á eftir.

Gengisfall krónunnar síðari hluta ársins 2007 og árið 2008 var talsvert meira en árin 2000 og 2001. Auk pess hafði skuldsetning íslenskra aðila í erlendri mynt eða með gengistryggingu aukist gríðarlega árin á undan. Til að bæta gráu ofan á svart höfðu margir lántakendur veðjað á lágvaxtamyntir, sérstaklega japanskt jen og svissneskan franka og pær myntir styrktust verulega á pessum tíma gagnvart öðrum mikilvægum myntum, svo sem evru, pundi og dollara. Pannig hækkaði jenið um 180\% gagnvart krónu frá júlí 2007 til mars 2010 á meðan evran hækkaði um 108\%, dollar 110\% og pundið um 56\%. Áhrif gengisfallsins 2007 og 2008 voru pví mjög mikil.

Enn skipta tímasetningar höfuðmáli. Sá sem hefði tekið lán í jenum í júlí 2007 með LIBOR vöxtum og greitt pað upp í desember 2009 hefði t.d. purft að greiða sem samsvarar um 76\% raunvöxtum á ári, mælt í krónum á föstu verðlagi.

Prátt fyrir petta mikla gengisfall krónunnar 2007 og 2008 hafa erlend lán pegar til langs tíma er litið pó sögulega verið hagstæðari en lán í krónum. Petta endurspeglar fyrst og fremst kerfisbundið háa raunvexti hérlendis sem með tíð og tíma vega meira en skammtíma gengissveiflur. Sá sem hefði tekið lán á LIBOR vöxtum í jenum snemma árs 1999 hefði í september 2010 verið búinn að fá reiknaða raunvexti í íslenskum krónum upp á 2,1\%. ${ }^{8}$ Hefði

${ }^{8}$ Í öllum tilfellum eru raunvextir reiknaðir út frá vísitölu neysluverðs án húsnæðis. Miðað er við LIBOR og REIBOR vexti til eins mánaðar. Rétt er að hafa í huga að almennir lántakendur purfa alla jafna að greiða álag ofan á LIBOR eða REIBOR vexti. Bæta má pví ofan á fyrrnefnda vexti en pað breytir ekki samanburðinum á milli einstakra mynta í grundvallaratriðum. Hér verður ekki farið út í að skoða verðtryggða íslenska vexti en að jafnaði má gera ráð fyrir að peir séu pegar til lengdar lætur nokkuð hagstæðari fyrir lántakendur en vextir á óverðtryggðum lánum auk pess sem greiðslubyrði er 
Tafla 1: Raunvextir á lánum í nokkrum myntum

\begin{tabular}{|c|c|c|c|c|c|}
\hline ISK & \multicolumn{5}{|c|}{ Meðalraunvextir m.v. mismunandi lántöku- og uppgreiðslutíma } \\
\hline Inn \Út & Feb. 2001 & Júní 2004 & Júlí 2007 & Des. 2009 & Sept. 2010 \\
\hline Feb. 1999 & $6,91 \%$ & $5,48 \%$ & $6,52 \%$ & $5,32 \%$ & $5,35 \%$ \\
\hline Feb. 2001 & & $4,63 \%$ & $6,40 \%$ & $4,96 \%$ & $5,02 \%$ \\
\hline Júní 2004 & & & $8,36 \%$ & $5,16 \%$ & $5,23 \%$ \\
\hline Júlí 2007 & & & & $1,08 \%$ & $2,20 \%$ \\
\hline Des. 2009 & & & & & $5,75 \%$ \\
\hline
\end{tabular}

Jen Meðalraunvextir m.v. mismunandi lántöku-og uppgreiðslutíma

\begin{tabular}{rlllll|} 
Inn \Út & Feb. 2001 & Júní 2004 & Júlí 2007 & Des. 2009 & Sept. 2010 \\
\cline { 2 - 6 } Feb. 1999 & $5,19 \%$ & $-2,42 \%$ & $-5,13 \%$ & $2,34 \%$ & $2,12 \%$ \\
Feb. 2001 & & $-6,71 \%$ & $-8,13 \%$ & $1,70 \%$ & $1,49 \%$ \\
Júní 2004 & & & $-9,65 \%$ & $7,25 \%$ & $6,22 \%$ \\
Júlí 2007 & & & & $34,53 \%$ & $24,87 \%$ \\
Des. 2009 & & & & & $-0,96 \%$ \\
\hline
\end{tabular}

\begin{tabular}{|c|c|c|c|c|c|}
\hline Inn \Út & Feb. 2001 & Júní 2004 & Júlí 2007 & Des. 2009 & Sept. 2010 \\
\hline Feb. 1999 & $-0,51 \%$ & $1,21 \%$ & $0,34 \%$ & $5,42 \%$ & $3,26 \%$ \\
\hline Feb. 2001 & & $2,25 \%$ & $0,60 \%$ & $6,83 \%$ & $4,08 \%$ \\
\hline Júní 2004 & & & $-1,15 \%$ & $9,75 \%$ & $5,08 \%$ \\
\hline Júlí 2007 & & & & $26,01 \%$ & $11,69 \%$ \\
\hline Des. 2009 & & & & & $-23,25 \%$ \\
\hline
\end{tabular}

hann á sama tíma tekið lán í krónum á REIBOR vöxtum hefðu vextirnir verið 5,3\%. Aðrar erlendar myntir hefðu einnig verið hagstæðari en krónan yfir petta tímabil, lán í dollurum hefði kostað 2,5\%, í evrum 3,2\%, pundum 3,6\% og svissneskum frönkum 3,4\%. Sjá nánar mynd 6 og töflu 1.

Miðað er við nafnhækkun umfram vísitölu neysluverðs án húsnæðis. Nafnvextir eru REIBOR vextir á lánum í krónum en LIBOR í erlendri mynt. Inn=lántökutími, út=uppgreiðslutími.

Haldist pessi raunvaxtamunur á milli krónunnar og erlendra mynta næstu árin pá munu jafnvel pau lán sem tekin voru í erlendri mynt á versta tíma, um mitt ár 2007, pegar til lengdar lætur verða mun hagstæðari en nú virðist. Petta gerist jafnvel pótt raungengi krónunnar hækki ekki frá pví sem nú er.

Sem dæmi má miða við pær forsendur að raungengi krónunnar haldist óbreytt frá september 2010 og að meðalraunvextir á lánum í hinum ýmsu myntum verði peir sömu og undanfarin 12 ár. Pá verða raunvextir á láni sem tekið var í krónum í júlí 2007 að jafnaði 4,8\% yfir 20 ára tímabil en 4,1\% í dollurum, 4,5\% í evrum og 4,0\% í pundum. ${ }^{9}$ Jen og svissneskir frankar verða aðeins óhagstæðari en krónur en pó munar ekki miklu. Meðalraunvextir á láni

jafnari.

${ }^{9}$ Miðað er við að ekkert sé greitt af höfuðstól lánanna á lánstímanum. Niðurstaðan verður svipuð ef gert er ráo fyrir lánum til 35 ára sem greitt er af jafnt og pétt á lánstímanum. Áhrif af skammtímagengissveiflum eru mun meiri á lánum til skamms tíma og pá skiptir vaxtamunur minna máli. 
Tafla 2: Eignabóla, nokkrar lykilstærðir

\begin{tabular}{|c|c|c|c|c|c|}
\hline & $\begin{array}{l}\text { Hækkun } \\
\text { hefst }\end{array}$ & $\begin{array}{l}\text { Hækkun } \\
\text { lýkur }\end{array}$ & Raunhækkun & $\begin{array}{l}\text { Lækkun } \\
\text { lýkur* }\end{array}$ & Raunlækkun \\
\hline Hlutabréf & Ágúst 2001 & Júlí 2007 & $694 \%$ & Apríl 2009 & $97 \%$ \\
\hline Fasteignir & Apríl 2002 & $\begin{array}{l}\text { Október } \\
2007\end{array}$ & $106 \%$ & Apríl 2010 & $39 \%$ \\
\hline Króna & $\begin{array}{l}\text { Nóvember } \\
2001\end{array}$ & $\begin{array}{l}\text { Nóvember } \\
2005\end{array}$ & $46 \%$ & $\begin{array}{l}\text { Nóvember } \\
2008\end{array}$ & $46 \%$ \\
\hline
\end{tabular}

í jenum verða m.v. pessar forsendur 5,3\% og í frönkum 5,7\%. Sé reiknað miðað við lántökudag nokkru fyrir júlí 2007 eða nokkru síðar verða lán í jenum og frönkum einnig hagstæðari en lán í krónum pegar til lengdar lætur.

\subsection{Tímasetningar og vogun}

Eins og sjá má á umfjölluninni að framan pá skipta tímasetningar höfuðmáli við að ákvarða hvernig einstakir fjárfestar verða fyrir áhrifum af sveiflum undangenginna ára á eignamörkuðum. Peir sem keyptu hlutabréf eða fasteignir eða tóku erlend lán nógu snemma og losuðu pessar stöður áður en bólan sprakk hafa væntanlega í flestum tilfellum komið afar vel út.

Í pessu samhengi er áhugavert að bein pátttaka almennings á hlutafjármarkaði jókst mjög á níunda og tíunda áratug síðustu aldar, m.a. vegna skattfríðinda sem í boði voru og vegna svokallaðrar kennitölusöfnunar í tengslum við sölu ríkisfyrirtækja. Hins vegar fækkaði peim einstaklingum sem áttu hlutabréf í skráðum fyrirtækjum mjög upp úr aldamótum. Skýringar á pví liggja ekki fyrir. Væntanlega skiptir pó m.a. máli að talsvert var um að fyrirtæki væru keypt og í kjölfarið skráð af hlutabréfamarkaði.

Peir einstaklingar sem keyptu bréf á níunda og tíunda áratugnum og seldu fljótlega upp úr aldamótum hafa að jafnaði fengið mjög góða ávöxtun á sitt fé og auk pess í mörgum tilfellum skattaafslátt. Svipað á við um marga lífeyrissjóði sem tóku snemma pátt á íslenska hlutabréfamarkaðinum en seldu meira en peir keyptu síðustu árin fyrir hrun, m.a. til að halda hlutfalli hlutabréfa í eignasafni sínu innan tilskilinna marka. Peir hafa væntanlega að jafnaði komið ágætlega út úr viðskiptum sínum með íslensk hlutabréf til langs tíma pótt ávöxtun sé talsvert minni en hún var á pappír um mitt ár 2007. Lífeyrissjóðirnir hafa pó á móti einnig tapað á öðrum viðskiptum, t.d. með skuldabréf fyrirtækja og vegna gengisvarna árin 2007 og 2008.

Peir sem hins vegar keyptu pegar eignaverð var hvað hæst eða tóku erlend lán pegar gengið var hvað hæst hafa að jafnaði komið illa út. Í öllum tilfellum hafa peir sem voru með mjög lengi pó einnig komið ágætlega út að meðaltali, jafnvel pótt peir hafi ekki losað stöður sínar áđur en bólan sprakk. Pannig er meðalávöxtun hlutabréfa ágæt ef horft er allt til upphafsára markaðarins á níunda áratugnum. Раð sama má segja um fasteignamarkaðinn ef horft er aftur til ársins 2004 eða fyrr. Loks koma erlend lán prátt fyrir allt enn betur út en íslensk fyrir lántakendur sem tóku lán snemma, t.d. árið 2003 eða fyrr.

Vogun ýkir allar verðsveiflur. Peir sem notfærðu sér sífellda hækkun eignaverðs til að taka sífellt meiri lán hafa væntanlega flestir tapað mestu af eigin fé sínu pegar bólan sprakk. Oft er tapið hjá pessum aðilum mun meira en eigið fé lántaka og lendir pá á lánveitendum og raunar á endanum hjá peim sem lánuðu lánveitendunum. Afskriftirnar verða 
fyrirsjáanlega í krónum talið langmestar hjá peim pegar upp verður staðið.

Ponzi-leikur par sem framlag pátttakenda er að mestu lánsfé og peir hafa annað hvort takmarkaða ábyrgð eða takmarkað tapspol endar fyrirsjáanlega með ósköpum fyrir lánveitendur. Ef lánveitendurnir eru sjálfir mjög skuldsettir og hafa takmarkað tapspol endar tapið аð uppistöðu til hjá lánveitendum peirra og pannig koll af kolli. Рað varð enda niðurstaðan á Íslandi, eins og nánar verður vikið að síðar.

Pau fyrirtæki sem veðjuðu djarfast, svo sem Baugur, Exista, FL, Samson og Milestone, fóru á hausinn eða purftu nauðasamninga. Рað sama átti við um fjölmörg smærri fyrirtæki. Tjónið fyrir lánveitendur peirra varð miklu meira en peir réðu við og peir fóru líka á hausinn. Á endanum liggur porri tapsins hjá peim sem lánuðu lánveitendunum og eru nú kröfuhafar í protabú peirra með enga von um að fá nema brot af fé sínu til baka. Sumir peirra eru raunar líka komnir í vandræði eða jafnvel prot pannig að tap lendir pá einnig á lánveitendum peirra eða skattgreiðendum í heimalandi viðkomandi ef hið opinbera hefur komið til bjargar.

Á endanum parf allt tap að koma niður á eigin fé einhvers staðar í keðju fjármögnunaraðila. Petta má skýra með dæmi.

Gerum ráð fyrir að á hápunkti eignaverðsbólu séu viðskiptavinir banka á pappírnum með eignir upp á 12 púsund milljarða, par af 10 púsund milljarða að láni og 2 púsund milljarða í eigið fé. Bankinn sé sjálfur með 1 púsund milljarða í eigin fé og 9 púsund milljarða að láni. Pegar eignaverðsbólan springur verða eignir viðskiptavinanna 5 púsund milljarða virði. Pá tapa viðskiptavinirnir öllu sínu eigin fé og raunar 5 púsund milljörðum betur. Bankinn tapar öllu sínu eigin fé og 4 púsund milljörðum betur. Pví tapa lánveitendur bankans 4 púsund milljörðum. Standi eigið fé peirra ekki undir pví pá tapa lánveitendur peirra pví sem út af stendur og pannig koll af kolli.

\subsection{Hvert fóru peningarnir?}

Ein áleitnasta spurningin pegar litið er yfir hrunið Ponzi-kerfi er: Hvert fóru peningarnir? Svarið við pví er í grunninn einfalt. Peir sem ná sínu fé út áður en halla tekur undan fæti geta hagnast verulega. Par endar féð.

Íslenska dæmið er flóknara en hið einfalda kerfi Charles Ponzi en sama grundvallarlögmál gildir pó. Pví er eðlilegt að spyrja: Hverjir nádu sínu fé út? Og ennfremur: Hvar er fé peirra?

Í grófum dráttum má lýsa skiptingu hinna ýmsu hópa sem áttu fé undir í hinu íslenska hagkerfi eitthvað á pá leið sem gert er í töflu 3. Taflan er pó engan veginn tæmandi og í henni felst veruleg einföldun. 
Tafla 3: Pátttakendur í íslenska Ponzi-leiknum

\begin{tabular}{|c|c|c|c|c|}
\hline & Hlutabréfamarkaður & Fasteignamarkaður & Krónumarkaður & Lánveitandi \\
\hline Hið opinbera & $\begin{array}{l}\text { + Fékk verulegar } \\
\text { skatttekjur í } \\
\text { uppsveiflunni. } \\
\text { + Seldi ýmsar eignir á } \\
\text { háu verði, t.d. } \\
\text { Símann. }\end{array}$ & $\begin{array}{l}\text { + Fékk verulegar } \\
\text { tekjur í uppsveifl- } \\
\text { unni, m.a. af lóðasölu, } \\
\text { stimpilgjöldum. } \\
\text { - Sat uppi með } \\
\text { offjárfestingu vegna } \\
\text { hálfbyggðra hverfa. }\end{array}$ & $\begin{array}{l}\text { + Langtímalán í } \\
\text { erlendri mynt } \\
\text { hagstæð. } \\
\text { - Einstaka sveitarfélög } \\
\text { í vanda vegna } \\
\text { hækkunar erlendra } \\
\text { skulda. }\end{array}$ & $\begin{array}{l}\text { - Tapaði stórfé } \\
\text { vegna veðlána } \\
\text { Seðlabanka og } \\
\text { vegna Icesave. }\end{array}$ \\
\hline Lífeyrissjóðir & $\begin{array}{l}\text { + Tóku stöðu snemma } \\
\text { og voru síðan } \\
\text { nettóseljendur. }\end{array}$ & & $\begin{array}{l}\text { + Högnuðust á } \\
\text { gengisvörnum } \\
\text { framan af. } \\
\text { - Töpuðu á gengis- } \\
\text { vörnum undir lokin. } \\
\text { + Fjárfestu erlendis á } \\
\text { hagstæðu gengi. }\end{array}$ & $\begin{array}{l}\text { - Töpuðu stórfé á } \\
\text { lánum til banka og } \\
\text { fyrirtækja. }\end{array}$ \\
\hline $\begin{array}{l}\text { Heppnir } \\
\text { útrásarvíkingar } \\
\text { (seldu snemma) }\end{array}$ & $\begin{array}{l}\text { + Seldu áður en verð } \\
\text { lækkaði. }\end{array}$ & $\begin{array}{l}\text { + Seldu áður en verð } \\
\text { lækkaði. }\end{array}$ & $\begin{array}{l}\text { + Komu fé sínu í } \\
\text { erlenda mynt } \\
\text { snemma. }\end{array}$ & \\
\hline $\begin{array}{l}\text { Óheppnir } \\
\text { útrásarvíkingar }\end{array}$ & $\begin{array}{l}\text { + Græddu ótæpilega } \\
\text { framan af. } \\
\text { - Sátu uppi með } \\
\text { vogaðar stöður pegar } \\
\text { markaður hrundi. }\end{array}$ & $\begin{array}{l}\text { + Græddu ótæpilega } \\
\text { framan af. } \\
\text { - Sátu uppi með } \\
\text { vogaðar stöður pegar } \\
\text { markaður hrundi. }\end{array}$ & $\begin{array}{l}\text { + Græddu ótæpilega } \\
\text { framan af. } \\
\text { - Sátu uppi með } \\
\text { vogaðar stöður pegar } \\
\text { markaður hrundi. }\end{array}$ & \\
\hline $\begin{array}{l}\text { Smáir hluthafar / } \\
\text { stofnfjáreigendur }\end{array}$ & $\begin{array}{l}\text { + Keyptu snemma og } \\
\text { voru keyptir út } \\
\text { snemma. }\end{array}$ & & & \\
\hline $\begin{array}{l}\text { Óheppnir smáir } \\
\text { hluthafar / } \\
\text { stofnfjár-eigendur }\end{array}$ & $\begin{array}{l}\text { - Sátu uppi með } \\
\text { vogaðar stöður pegar } \\
\text { markaður hrundi. }\end{array}$ & & $\begin{array}{l}\text { - Sátu uppi með } \\
\text { erlend lán pegar } \\
\text { markaður hrundi. }\end{array}$ & \\
\hline $\begin{array}{l}\text { Heppnir fasteigna- } \\
\text { eigendur (keyptu } \\
\text { fyrir 2004) }\end{array}$ & & $\begin{array}{l}\text { + Hafa fengið ágæta } \\
\text { ávöxtun á fasteigna- } \\
\text { markaði og afnot af } \\
\text { húsnæði. }\end{array}$ & & \\
\hline $\begin{array}{l}\text { Óheppnir } \\
\text { fasteignaeigendur } \\
\text { (keyptu fyrstu } \\
\text { íbúd eftir 2004) }\end{array}$ & & $\begin{array}{l}\text { - Hafa fengið } \\
\text { neikvæða ávöxtun á } \\
\text { fasteignamarkaði en } \\
\text { pó afnot af húsnæði. }\end{array}$ & & \\
\hline $\begin{array}{l}\text { Erlendir seljendur } \\
\text { eigna }\end{array}$ & $\begin{array}{l}\text { + Brosa út að eyrum } \\
\text { yfir verðinu sem } \\
\text { Íslendingar greiddu. }\end{array}$ & $\begin{array}{l}\text { + Brosa út að eyrum } \\
\text { yfir verðinu sem } \\
\text { Íslendingar greiddu. }\end{array}$ & & \\
\hline $\begin{array}{l}\text { Heppnir } \\
\text { krónubréfa- } \\
\text { spákaupmenn } \\
\text { (fóru snemma af } \\
\text { markaðinum) }\end{array}$ & & & $\begin{array}{l}\text { + Græddu á vaxta- } \\
\text { mun og gengispróun. }\end{array}$ & \\
\hline $\begin{array}{l}\text { Óheppnir } \\
\text { krónubréfa- } \\
\text { spákaupmenn } \\
\text { (brunnu inni) }\end{array}$ & & & $\begin{array}{l}\text { - Töpuðu á } \\
\text { gengispróun og sitja } \\
\text { nú fastir vegna hafta. }\end{array}$ & \\
\hline $\begin{array}{l}\text { Erlendir } \\
\text { lánveitendur } \\
\text { bankanna }\end{array}$ & & & & $\begin{array}{l}\text { - Töpuðu } \\
\text { gríðarlegu fé. }\end{array}$ \\
\hline
\end{tabular}


Tafla 3 dregur fram að ýmsir hópar hafa að öllum líkindum komið nokkuð vel út fjárhagslega úr sviptingum undanfarinna ára. Enn eru enda til nokkrir íslenskir milljarðamæringar pótt peim hafi fækkað til muna og milljörðunum fækkað. Pá högnuðust ýmsir erlendir aðilar augljóslega mjög mikið pegar peir seldu íslenskum aðilum eignir á háu verði. Ljóst er að kaup íslenskra aðila á fyrirtækjum og öðrum eignum, svo sem fasteignum erlendis, voru einkum gerð pegar verð peirra var mjög hátt. Pví má ekki gleyma að pótt íslenska eignaverðsbólan hafi verið í nokkrum sérflokki var bólan alpjóðleg. Pví til viðbótar var flumbrugangur íslensku útrásarvíkinganna slíkur að peir virðast hafa gert verri kaup en almennt tíðkaðist. Seljendurnir hafa pví í mörgum tilfellum hagnast vel, a.m.k. ef söluverðið er borið saman við kaupverð nú, eftir að hin alpjóðlega eignaverðsbóla hefur hjaðnað. Hið lága verð nú skiptir hins vegar sköpum fyrir endurheimtur úr protabúum viðskiptavelda útrásarvíkinganna og banka peirra.

Раð er verðugt verkefni að reyna að kortleggja pessa ýmsu hópa betur en pað verður pó ekki gert hér. Hins vegar er hægt að draga fram ýmsar heildartölur úr pjóðhagsreikningum sem varpa ljósi á pað hvernig pjóðarbúið sem heild kemur út úr pessu fjárhagslega. Pótt einstakir hópar verði ekki skoðaðir verður pó einnig dregið fram hvernig hið opinbera kemur út fjárhagslega.

\section{Bankastræti og Laugavegur}

Peningalegar eignir (t.d. hlutabréf og skuldabréf) eru ekki raunveruleg verðmæti heldur eins konar ávísanir á slík verðmæti. Eyðileggingu peningalegra eigna fylgir ekki sjálfkrafa eyðilegging raunverulegra verðmæta en hins vegar fylgir peim mikil eignatilfærsla. Frá sjónarhóli peirra sem áttu slíkar eignir er tjónið raunverulegt.

Pegar tölur um pjóðarbúskapinn eru skoðaðar, t.d. um landsframleiðslu, kaupmátt, eignir og skuldir, er rétt að hafa í huga að heildartölur eða meðaltöl segja ekki alla söguna. Tekju- og eignaskiptingin skiptir ekki minna máli.

Róttækustu áhrif bólunnar og hrunsins eru vegna breytinga á tekju- og eignaskiptingu. Breytingar á meðaltölum eru oftast miklu minni.

Tjón í fjármálakreppu fyrir hagkerfið (eða pjóðarbúið) i heild verður fyrst og fremst við раð аð raunveruleg verðmæti glatast eða ef framleiðsla dregst saman um lengri eða skemmri tíma. Hugsanlegur samdráttur vergrar landsframleiðslu skiptir hér mestu. Hann er óneitanlega raunverulegt tjón.

Brýnt er að ná tökum á atvinnuleysi og vannýttri framleiðslugetu vegna pessa.

Langtímahagvöxtur skiptir einnig miklu máli. Hugsanleg aukning erlendra skulda eða tap erlendra eigna getur einnig vegið pungt.

Til að átta sig betur á muninum á raunverulegum eignum og peningalegum er ágætt að styðjast við tvískiptingu hagkerfisins sem oft er notuð í Bandaríkjunum. Par ræða menn annars vegar um fjármálakerfið, Wall Street, og hins vegar um raunhagkerfið, Main Street. Á Íslandi hefði eitt sinn mátt tala á sama hátt um Bankastræti og Laugaveg en nú er langt síðan banki hefur verið í Bankastræti og Laugavegur hefur látið nokkuð á sjá sem miðstöð verslunar.

Hið íslenska fjármálakerfi, Wall Street, hrundi vissulega. Öll helstu fjármálafyrirtæki landsmanna fóru í prot. Einu undantekningarnar voru nokkur smá fyrirtæki. Jafnframt eyðilagðist eða stórskemmdist stór hluti peirra eigna sem pessar stofnanir höfðu sýslað með, p.e. hinar ýmsu peningalegu eignir. Eyðilegging peningalegra eigna varð slík að aldrei hefur neitt sambærilegt gerst í öðru landi, í hlutfalli við stærð viðkomandi hagkerfis. 
Hins vegar hrundi íslenska raunhagkerfið, Main Street, ekki. Рað heldur áfram að framleiða vörur og pjónustu og veita atvinnu. Vitaskuld hefur pað orðið fyrir pungu höggi og parf að taka ýmsum breytingum en í öllum grundvallaratriðum er pað vel starfhæft. Á peim tveimur árum sem liðin eru frá hruni fjármálakerfisins, frá október 2008, hefur íslenska hagkerfið framleitt vörur og pjónustu fyrir meira en prjú púsund milljarða króna. •að er í raun ótrúlegt afrek í ljósi pess sem kom fyrir fjármálakerfið.

Til pess að petta væri hægt purfti margt að takast. Рað sem skipti mestu var að fá að nýju starfhæft fjármálakerfi og sérstaklega að halda greiðslumiðlun og innstæðukerfi gangandi. Pað tókst. Án pess hefði raunhagkerfið að öllum líkindum einnig hrunið. Nútíma hagkerfi gæti ekki starfað á grundvelli reiðufjárviðskipta nema í örstuttan tíma. Innlend greiðslumiðlun stöðvaðist aldrei. Erlend greiðslumiðlun gekk mjög illa um skeið en síðan tókst einnig að koma henni í ásættanlegt horf. Viðskipti við útlönd virðast pví almennt ekki hafa orðið fyrir varanlegum skakkaföllum. Helsta undantekningin er að aðgangur íslenskra aðila að erlendum fjármálamörkuðum er langt frá pví að vera kominn í ásættanlegt horf aftur. •аð skiptir vitaskuld verulegu máli. Með samvinnu við Alpjóða gjaldeyrissjóðinn og samningum við Norðurlöndin og Pólland í tengslum við hana hefur pó verið tryggt nægt fjármagn til að mæta fjárpörf hins opinbera.

\subsection{Eyddum við öllu pessu fé?}

Pegar petta er ritað, haustið 2010, liggur ekki fyrir uppgjör vegna hruns íslenska fjármálakerfisins. Raunar er fyrirsjáanlegt að pað mun taka nokkur ár áður en myndin verður orðin sæmilega skýr. Par skiptir mestu hvernig uppgjöri protabúa hinna föllnu banka miðar áfram. Við pað kemur í ljós hvaða kröfur í pau verða viðurkenndar og hve mikið verður á endanum greitt upp í pær. Á meðan niðurstaðan úr pví ferli liggur ekki fyrir verða íslenskir pjóðhagsreikningar allnokkurri óvissu háðir. Sérstaklega pýðir petta að mat á erlendum skuldum pjóðarbúsins og hreinni erlendri stöðu pess verður ónákvæmt. M.a. vegna pess verður mat á páttatekjum til og frá útlöndum ónákvæmt og par með mat á pjóðartekjum. Ekki verður eingöngu óvissa um pessar stærðir í nútíma, heldur einnig hverjar pær voru í raun á nýliðnum árum.

Prátt fyrir petta verður hér reynt að leggja mat á helstu stærðir, p.e. hvernig skellurinn vegna hruns íslenska fjármálakerfisins skiptist á nokkra lykilaðila. Đað verður pó aldrei annað en gróft mat og gera verður ýmsa fyrirvara við pað.

Farin verður sú leið að miða við sem byrjunarreit stöðu sem er nokkuð vel pekkt, p.e. mat á hreinni stöðu pjóðarbúsins gagnvart útlöndum í lok árs 2002. Á peim tíma var íslenska bólan lítt panin og hafði raunar hjaðnað aðeins árin 2000 og 2001 með lækkun hlutabréfaverðs og gengis krónunnar og rólegum fasteignamarkaði. Einkavæðingu bankanna var rétt að ljúka en mestu vaxtarár peirra voru framundan. Árið 2002 voru utanríkisviðskipti einnig í óvenju góðu jafnvægi, lítilsháttar afgangur var á viðskiptum við útlönd í fyrsta sinn síðan árið 1995.

Í lok ársins 2002 var svokölluð hrein staða pjóðarbúsins gagnvart útlöndum neikvæð um 562 milljarða króna. Раð pýðir að allar erlendar skuldir landsmanna, bæði einkageira og hins opinbera, að viðbættum öðrum eignum erlendra aðila hérlendis, t.d. eigin fé fyrirtækja sem eru að hluta eða öllu leyti í erlendri eigu, voru petta mikið hærri en sú upphæð sem erlendir aðilar skulduðu íslenskum að viðbættum eignum Íslendinga í útlöndum. Á verðlagi ársins 2009 gerir petta rétt um 860 milljarða króna.

Árin 2003 til 2008 eyddu Íslendingar mun meiru erlendis en peir öfluðu. Рað var mjög mikill halli á viðskiptajöfnuði öll árin og sum árin hefur hann sjálfsagt nálgast heimsmet, í 


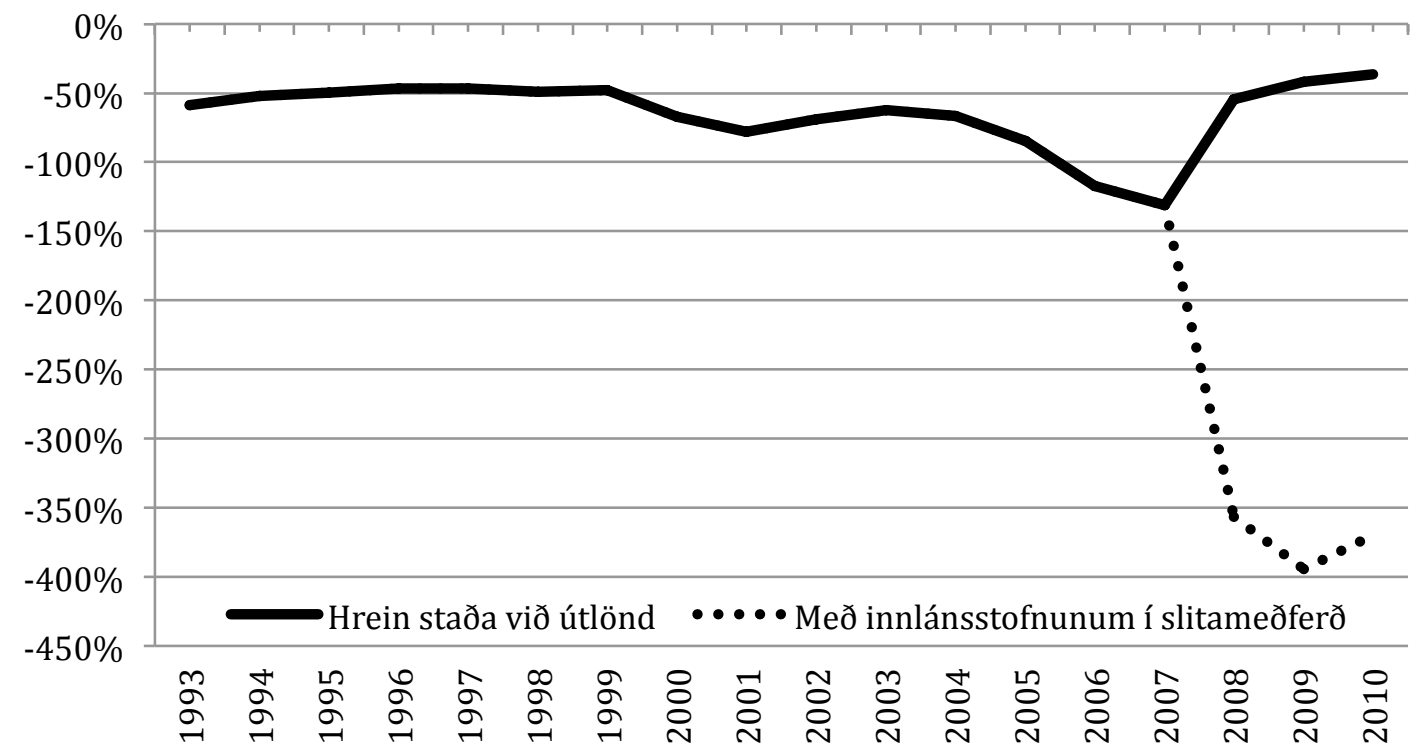

Mynd 7. Hrein staða við útlönd í hlutfalli við verga landsframleiðslu

Heimild: Seðlabanki Íslands.

hlutfalli við landsframleiðslu. Árið 2009 dró loks verulega úr innflutningi svo að utanríkisviðskipti færðust nær jafnvægi aftur. ${ }^{10}$ Uppsafnaður halli á viðskiptajöfnuði árin 2003 til 2009 var rétt um 1.380 milljarðar króna á verðlagi ársins 2009.

Eftir svo ofboðslegan hallarekstur ætti hrein staða pjóðarbúsins gagnvart útlöndum að hafa versnað til muna, raunar um svipaða upphæð og hallinn var. Sé horft á pjóðarbúið í heild, með protabúum hinna föllnu banka, er pað einnig niðurstaðan. Raunar eru opinberar tölur Seðlabankans mun verri en petta. Skv. peim var hrein staða pjóðarbúsins neikvæð um 5.911 milljarða í lok ársins 2009. Myndir 7 og 8 sýna annars vegar vergar erlendar skuldir pjóðarbúsins frá 1993 til miðs árs 2010 og hins vegar hreina peningalega stöðu pess gagnvart útlöndum, annars vegar með protabúum hinna föllnu banka og hins vegar án peirra.

Hinir föllnu bankar eru protabú í slitameðferð. Pegar henni lýkur hverfa eignir peirra og skuldir að mestu úr reikningum pjóðarbúsins. Раð sem eftir mun standa og máli skiptir verða pær íslensku eignir eða kröfur á íslenska aðila sem erlendir aðilar eignast í uppgjörinu og pær eignir sem innlendir aðilar (kröfuhafar) eignast. Fyrir liggur að erlendir aðilar eru í miklum meiri hluta meðal kröfuhafa föllnu bankanna og jafnframt að megnið af eignum protabúanna eru erlendar. Megnið af greiðslum vegna uppgjörs bankanna verður pví fólgið í pví að afrakstur af sölu erlendra eigna rennur til erlendra aðila en pað hefur ekki bein áhrif á íslenskt pjóðarbú.

Sé horft á hreina stöðu pjóðarbúsins gagnvart útlöndum án hinna föllnu banka kemur allt önnur mynd í ljós. Skv. mati Seðlabankans var pessi staða neikvæð um 628 milljarða í lok ársins 2009. Sé pessi tala borin saman við töluna í árslok 2002 á sama verðlagi kemur í ljós að staðan hefur batnað um u.p.b. 230 milljarða króna. Раð er vitaskuld með hreinum ólíkindum ef íslenskir aðilar hafa eytt 1.380 milljörðum króna meiru en peir öfluðu árin 2003 til 2009 en

${ }^{10}$ Pað er nokkur óvissa um pað hver viðskiptajöfnuður ársins 2009 var í raun vegna pess að erfitt er að leggja mat á greiðslur sem snúa að hinum föllnu bönkum, t.d. áfallna vexti á skuldir peirra sem fyrirsjáanlega verða aldrei greiddir. Enginn vafi er hins vegar á pví að sé horft framhjá hinum föllnu bönkum var ríflegur afgangur af viðskiptajöfnuði petta ár. 


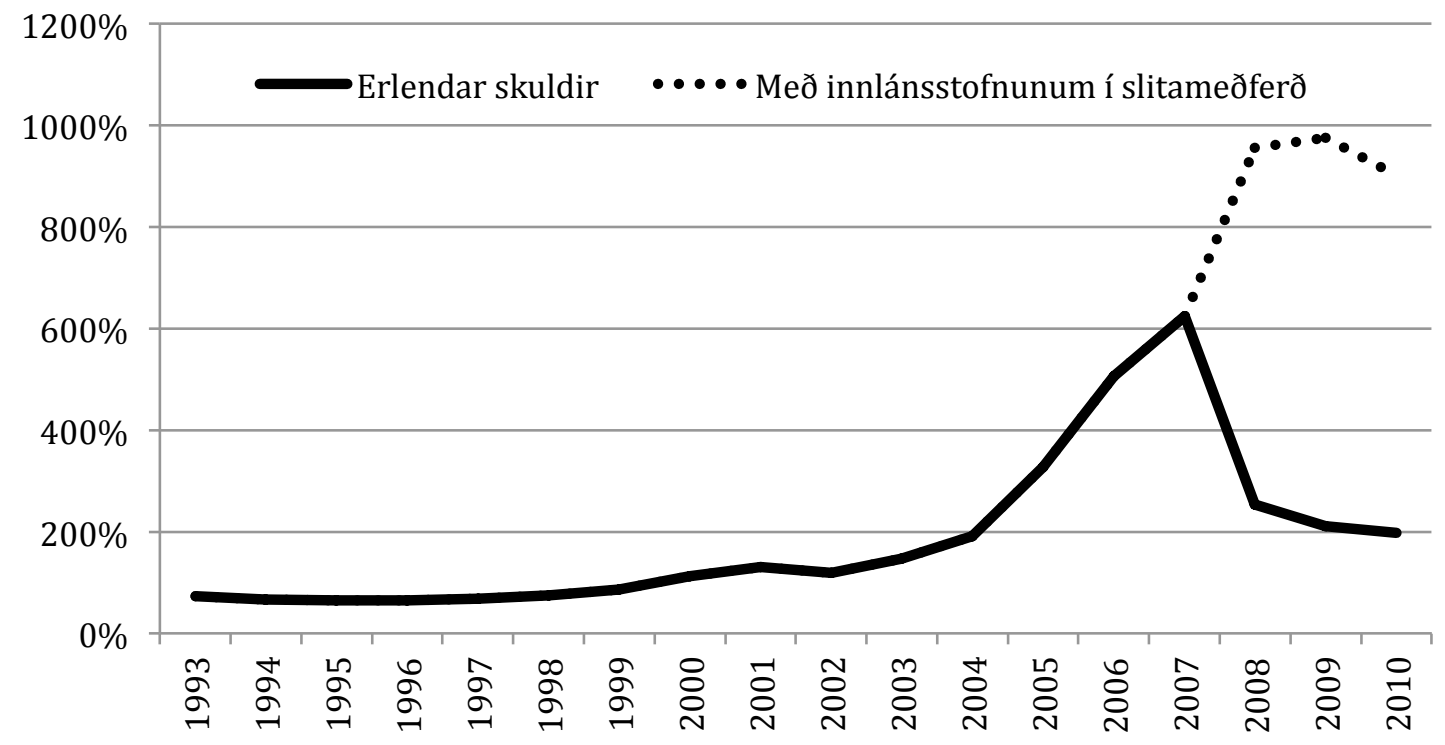

Mynd 8. Erlendar skuldir í hlutfalli við verga landsframleiðslu Heimild: Seðlabanki Íslands.

enda engu að síður með 230 milljörðum króna meira í hreina peningalega eign í lok tímabilsins en í upphafi pess.

Við pessa útreikninga verður sem fyrr segir að gera allnokkra fyrirvara. Peim verður hér skipt í nokkra liði.

\subsection{Matá hreinni stöđu}

Hugsanlegt er að innlendar eignir protabúa föllnu bankanna verði pegar upp er staðið meiri en pað sem innlendir aðilar fá greitt upp í kröfur sínar á hendur búunum. Sé pað raunin pá er fyrrnefnd tala, 628 milljarðar, vanmat á pví hve neikvæð hrein staða pjóðarbúsins (án protabúanna) er gagnvart útlöndum. Rétt er að hafa í huga í pessu samhengi að protabú Kauppings og Glitnis eiga óbeint megnið af hlutafé Arion-banka og Íslandsbanka. Рað er helsta innlenda eign protabúanna. Á móti kemur að ríkið á verulegar kröfur á protabúin, sérstaklega vegna veðlána sem Seðlabankinn veitti í aðdraganda hrunsins. Lífeyrissjóðir og fleiri innlendir aðilar eiga einnig umtalsverðar kröfur á protabúin.

Pá verður að taka tillit til væntanlegs uppgjörs vegna Icesave reikninga Landsbankans í mati á hreinni stöðu pjóðarbúsins. Sá hluti pess uppgjörs sem lendir á ríkissjóði bætist við fyrrnefnda tölu, 628 milljarða.

Pegar tekið er tillit til alls pessa er hugsanlegt að 628 milljarðar séu vanmat. Pví hafi hrein staða gagnvart útlöndum ekki batnað um 230 milljarða á árunum 2002 til 2009 heldur batnað um eitthvað minna eða jafnvel versnað lítillega. Um pað verður ekki fullyrt hér enda liggja tölurnar ekki fyrir. Hitt er óhætt að fullyrða að hrein staða gagnvart útlöndum hefur ekki versnað um neitt nálægt pví sem samsvarar uppsöfnuðum halla, 1.380 milljörðum. M.v. svartsýnasta mat á áhrifum uppgjörs protabúa bankanna og Icesave á hreina stöðu pjóðarbúsins gæti sú staða varla hafa versnað um meira en 200 milljarða frá árinu 2002.

\subsection{Mat á halla}

Mat á uppsöfnuðum halla á viðskiptajöfnuði byggir m.a. á mati á páttatekjum á tímabilinu. Рað veldur verulegri óvissu, sérstaklega árið 2009 og síðustu mánuði ársins 2008, pegar óljóst er hvernig reikna á og meta tekjur og gjöld sem tengjast protabúum bankanna. Jafnvel fyrir 


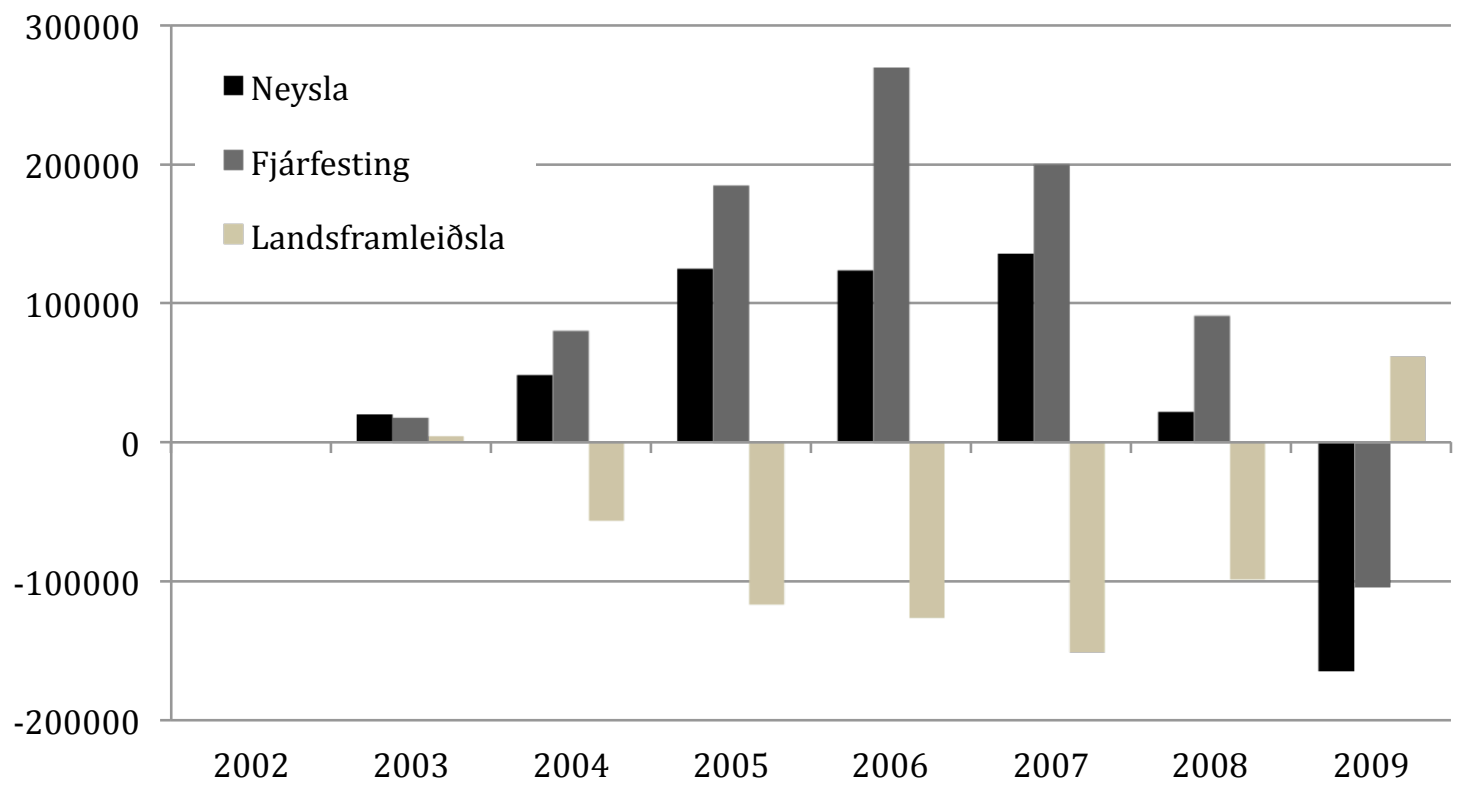

Mynd 9. Umframneysla, fjárfesting og landsframleiðsla

m.v. 2002 sem grunnár (milljónir króna á verðlagi 2009)

pann tíma var pó nokkrum erfiðleikum háð að ná utan um páttatekjurnar.

Vegna pessa verður hér einnig skoðuð önnur leið sem byggir á vergri landsframleiðslu. Nokkuð auðveldara ætti að vera að leggja mat á verga landsframleiðslu en pjóðartekjur við aðstæður eins og pær sem hafa verið hérlendis undanfarin ár. ${ }^{11}$

Aftur var byggt á árinu 2002 sem grunnári par sem hagkerfið var að flestu leyti í pokkalegu jafnvægi. Síðan var reiknað út hvernig landsframleiðsla og pjóðarútgjöld hefðu próast m.v. að í stað hins gríðarlega vaxtar sem hljóp í pessar stærðir hefðu pær vaxið að raunvirði á mann með sama hraða og verg landsframleiðsla á mann gerði að jafnaði árin par á undan, frá 1980 til 2001. Árin 1980 til 2001 var hagvöxtur, p.e. vöxtur vergrar landsframleiðslu á mann að raunvirði, um 2,08\% á ári. Рað var pví valinn viðmiðunarvöxtur landsframleiðslu og pjóðarútgjalda í pessu dæmi. Í reynd óx landsframleiðsla miklu örar en petta árin 2003 til 2007og pjóðarútgjöld enn örar en landsframleiðslan sem olli mjög miklum viðskiptahalla.

Niðurstaðan er teiknuð upp á mynd 9. Í viðmiðunardæminu er landsframleiðslan á árunum 2003 til 2009480 milljörðum minni en hún varð í raun, allt á verðlagi ársins 2009. Petta er pví sú upphæð sem pað skilaði að penja hagkerfið á yfirsnúningi pessi ár. Hins vegar varð fjárfesting 741 milljarði meiri í raun en í viðmiðunardæminu og neysla (einkaneysla og samneysla samanlögð) 307 milljörðum meiri. Athyglisvert er að í viðmiðunardæminu var samneysla örlítið meiri en hún varð í raun en einkaneysla peim mun minni. Pað er pví ekki hægt að skrifa penslu áranna 2003 til 2009 á mikinn vöxt samneyslu. Hins vegar jukust bæði einkaneysla og fjárfesting gríðarlega á pessum árum.

Með pví að draga pá umfram landsframleiðslu sem penslan bjó til (481 milljarðar) frá umfram neyslu og fjárfestingu (1.048 milljarðar) fæst nettó aukning upp á 567 milljarða. Líta má á pað sem sem pann hluta pjóðarútgjaldanna sem í reynd var fjármagnaður með erlendu fé. Раð er umtalsvert lægri upphæð en samanlagður reiknaður viðskiptahalli (1.380

11 Bæði verg landsframleiðsla og vergar pjóðartekjur eru gallaðir mælikvarðar á efnahagslíf pjóðar af ýmsum ástæðum sem ekki verða raktar hér. Pessir gallar skipta pó ekki höfuðmáli í pví samhengi sem hugtökin eru notuð hér. 
milljarðar). ${ }^{12}$ Рað er pó pað há upphæð að pegar breyting á hreinni stöðu gagnvart útlöndum (án hinna föllnu banka) er skoðuð blasir við að íslenskir aðilar hafa ekki eða munu ekki greiða petta nema e.t.v. að litlu leyti.

\subsection{Hvað situr pá eftir?}

Mikil fjárfesting undanfarinna ára skilur eftir gríðarleg mannvirki. Virkjanir og álver hafa verið mest í umræðunni en fleira skiptir máli, íbúðir, atvinnuhúsnæði, vegir, jarðgöng, hafnir og svo mætti lengi telja. Á árunum 2003 til 2008 voru t.d. öll met slegin í nýbyggingu íbúðarhúsnæðis. Samtals bættust ríflega 17 púsund íbúðir við pessi sex ár sem er um 6 púsund umfram pað sem búast hefði mátt við að jafnaði í venjulegu árferði. Pessi viðbót, 6 púsund íbúðir, samsvarar rétt ríflega priggja ára framleiðslu í meðalári.

Á verðlagi ársins 2009 var uppsöfnuð verg fjármunamyndun áranna 2003 til 20092.505 milljarðar króna. Hreinar tölur eru lægri, sem nemur afskriftum, en pó telst raunaukning fjármunaeignar vera 1.274 milljarðar árin 2003 til 2009, á verðlagi ársins 2009.

Ekki var bara fjárfest í steypu, sem betur fer. Veruleg fjölgun hefur orðið á útskrifuðum úr framhaldsskóla, háskóla og starfsnámi undanfarin ár. Frá árinu 2003 til ársins 2009 fjölgaði t.d. háskólamenntuðum Íslendingum um meira en 14 púsund eða rúmlega priðjung. Pessi mannauður er raunar ekki talin með í fjármunaeign landsmanna.

Neyslan skilur kannski minna eftir en mikil fjárfesting. Рað er pó ljóst að hún var einnig gríðarleg. Auðkýfingar og hátt launaðir starfsmenn, sérstaklega í bankakerfinu, bárust margir mikið á. Peirra neysla var pví áberandi og birtist m.a. í snekkjum, einkapotum og pyrlum, kaupum á erlendum fótboltaliðum, veislum sem Loðvík 14. hefði verið fullsæmdur af og mörgu fleiru. Рað er pó ljóst að ekki er hægt að skrifa nema hluta aukningar einkaneyslu árin 2003 til 2008 á pá. Afgangurinn liggur hjá almenningi sem hreifst með og naut meiri kaupmáttar, í utanlandsferðum, bílum, tjaldvögnum, flatskjám og svo mætti lengi telja. Árin 2005 til 2007 voru pannig fluttar inn meira en 20 púsund bifreiðar á ári, langt yfir pví sem tíðkast í meðalári. Sérstaklega var mikil aukning í innflutningi á dýrari tegundum bifreiða. Í lok ársins 2008 voru ökutæki á skrá á landinu 84\% fleiri en pau höfðu verið 14 árum áður.

\subsection{Range Rover vandinn}

Margt af pví sem keypt var eða reist í mesta uppganginum og pjóðin á nú hefði ekki verið fjárfest í undir eðlilegum kringumstæðum. Dýrir og óhagkvæmir bílar, t.d. Range Rover jeppar, eru eitt einkenni pessa en einnig margt af pví sem tengdist auðkýfingum sérstaklega, svo sem mörg hundruð milljóna króna einbýlishús eða sumarhallir. Hjá hinu opinbera má t.d. nefna tónlistarhúsið Hörpu. Sumt var hægt að selja úr landi pegar halla tók undan fæti, t.d. einkapotur. Pá má vitaskuld selja erlendar fasteignir. Annað er ekki hlaupið að pví að selja heldur verður pað að öllum líkindum nýtt innanlands framvegis, af fólki sem hefði ekki keypt pað fullu verði við núverandi aðstæður. Við mat á verðmæti pessa eignasafns verður að taka tillit til pessa og færa pað verulega niður. ${ }^{13}$ Pað er pó ekki hlaupið að pví að finna gott mat á verðmæti pessara eigna.

12 Munurinn liggur m.a. í pví hvernig tekið er tillit til páttatekna frá útlöndum. Pær eru neikvæðar (nettó) alla jafna á Íslandi sem veldur pví að pjóðartekjur eru minni en landsframleiðsla.

${ }^{13}$ Á sama hátt má færa rök að pví að hluti mikilla neysluútgjalda bóluáranna hafi verið hrein sóun, p.e. nyt peirra sem neyttu hafi engan veginn réttlætt fjárútlátin. Margir peirra sjá án efa eftir kostnaðinum. Hér verður ekki reynt að leggja mat á petta. 


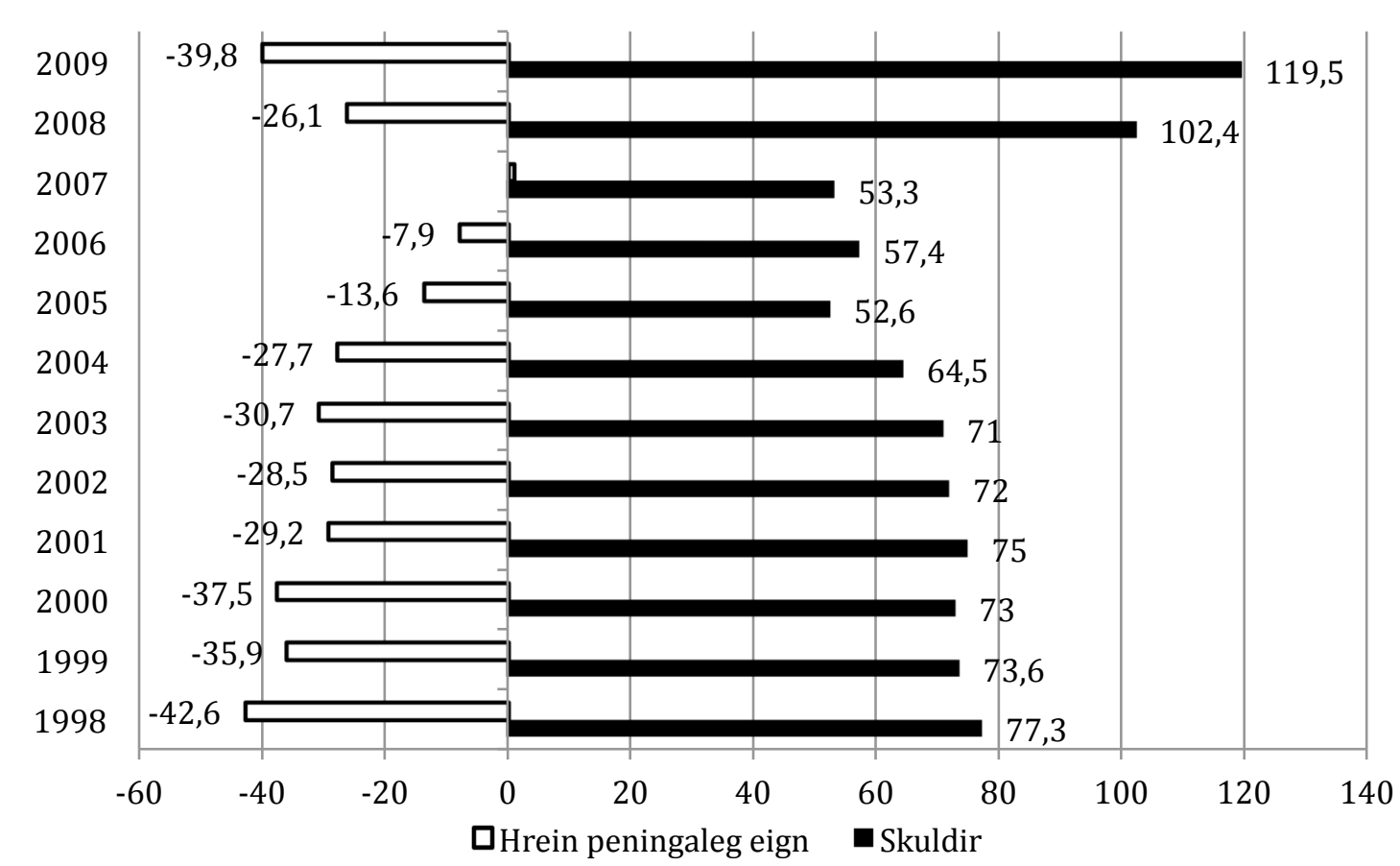

Mynd 10. Hrein peningaleg eign og vergar skuldir hins opinbera. Hlutfall af VLF. Heimild: Hagstofan.

Annað skylt vandamál er að lagt hefur verið í margs konar fjárfestingar í húsnæði, bæði íbúðar- og atvinnuhúsnæði og sumarhúsum, sem er talsvert umfram pað sem pörf er fyrir nú. Pótt petta húsnæði verði væntanlega á endanum í flestum tilfellum tekið í notkun verður pað vart fullnýtt næstu árin. Í sumum tilfellum er pó jafnvel ekki einu sinni ljóst hvort fasteignir eða fjárfestingar vegna peirra verða nokkurn tíma nýttar. аð á t.d. við um undirbúning vegna hverfa sem hugsanlega munu aldrei rísa, t.d. lagna- og gatnakerfi vegna peirra, og í einhverjum tilfellum nýrisnar eða hálfkláraðar fasteignir utan höfuðborgarsvæðisins. Taka verður tillit til pessa við mat á verðmæti sem getur verið talsvert undir peim kostnaði sem lagt hefur verið í. Mjög líklega eru einhver nýleg mannvirki í reynd einskis virði.

\subsection{Skuldir hins opinbera}

Við mat á hvort heldur er hreinni stöðu pjóðarbúsins við útlönd eða heildarskuldum er rétt að hafa í huga að pjóðin eða pjóðarbúið er ekki lögaðili og hvorki skuldar né á eignir. Рað gera hins vegar einkaaðilar, ríkið og sveitarfélög. Almennt gildir vitaskuld að hver ber ábyrgð á sínum skuldum og á sínar eignir. Pví skiptir ekki endilega höfuðmáli hvað kemur út ef öllum eignum og öllum skuldum allra er steypt saman, líkt og gert er í pjóðhagsreikningum. Skuldir einkafyrirtækja eru pannig fyrst og fremst áhyggjuefni peirra og lánardrottna peirra. Geti slíkur lántaki ekki staðið í skilum kemur pað öðrum oftast lítt við. Tölur um heildarskuldir pjóðarbúsins verður pví að túlka með varúð. Рað parf ekkert endilega að vera áhyggjuefni pótt pær séu umtalsverðar. ${ }^{14}$

Öðru máli gegnir um skuldir hins opinbera. Pær eru í raun sameiginlegt vandamál

14 Í pessu samhengi má t.d. benda á að vergar skuldir Lúxemborgara teljast vera ríflega fertugföld landsframleiðsla peirra og pví líklega hátt í tuttugu sinnum hærra hlutfall en vergar skuldir Íslendinga í hlutfalli við landsframleiðslu. Petta pykir pó ekkert sérstakt áhyggjuefni í Lúxemborg. 


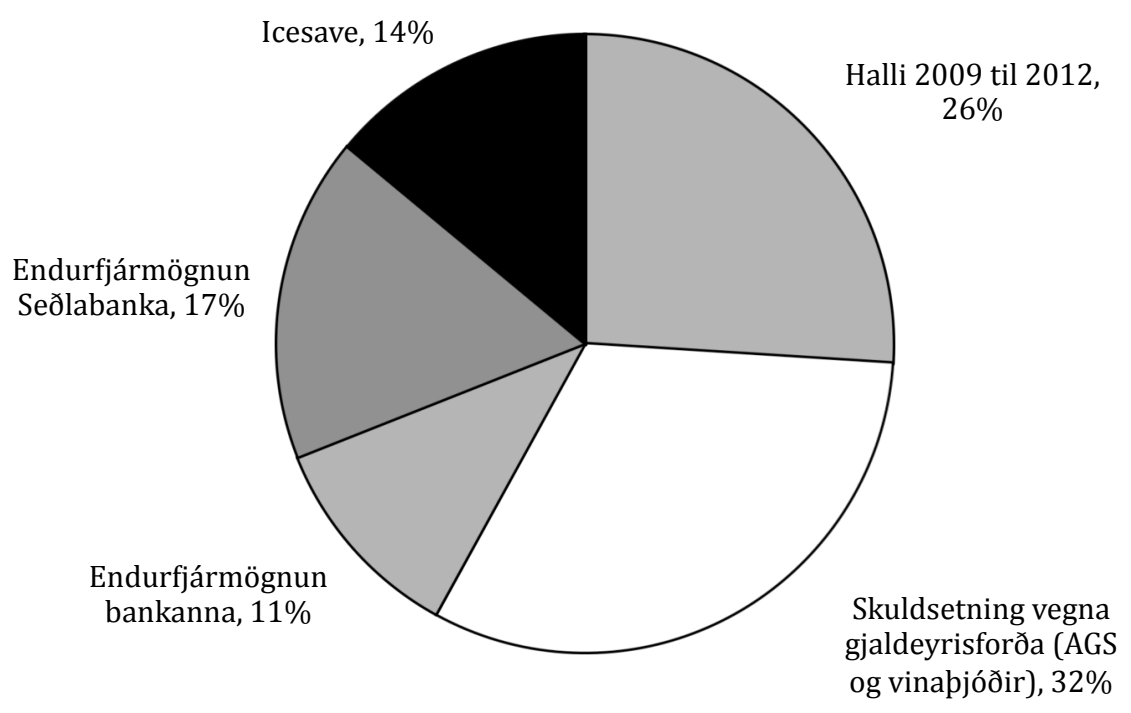

Mynd 11. Helstu ástæður aukningar skulda hins opinbera.

Hlutföll af vergri landsframleiðslu (mat vorið 2010) Heimild: Efnahags- og viðskiptaráðuneytið.

skattgreiðenda. Skuldir hins opinbera á Íslandi hafa aukist mjög mikið frá lokum ársins 2007. Staðan er hins vegar ekki verri en svo að hrein peningaleg eign hins opinbera, p.e. bæði ríkis og sveitarfélaga, er nánast sú sama og hún var árið 1998, í hlutfalli við landsframleiðslu. Með hreinni peningalegri eign er eins og nafnið gefur til kynna átt við peningalegar eignir (skuldabréf, innstæður, hlutabréf o.p.u.l.) að frádregnum skuldum. Pessi stærð taldist neikvæð um sem samsvarar 39,8\% af landsframleiðslu í lok ársins 2009 en var neikvæð um 42,6\% af landsframleiðslu í lok ársins $1998 .{ }^{15}$ Sjá nánar mynd 10

Á pessu árabili gekk vitaskuld talsvert á. Frá 1998 til 2007 jókst hrein peningaleg eign nánast á hverju ári uns hún var orðin örlítið jákvæð í lok ársins 2007. Að uppistöðu til má segja að pessi bati hafi verið vegna áhrifa eignaverðsbólunnar á rekstur hins opinbera. Flestir skattstofnar bólgnuðu út. Hagnaður fyrirtækja og aukning kaupmáttar skilaði tekjusköttum, hækkun fasteignaverðs skilaði fasteignagjöldum, aukin velta virðisaukaskatti, aukinn innflutningur aðflutningsgjöldum, aukin umsvif á lánamarkaði stimpilgjöldum og svo mætti lengi telja. Auk pess fékk ríkið talsverðar tekjur af sölu eigna, sérstaklega Símans. Hið opinbera fékk svo sannarlega sinn skerf af góðærinu prátt fyrir lækkun á ýmsum skatthlutföllum.

Staðan versnaði síðan til muna árin 2008 og 2009. Par komu einkum prír liðir við sögu. Hallarekstur hins opinbera skipti mestu, pá tap Seðlabankans vegna veðlána og loks fyrirsjáanlegur kostnaður vegna Icesave. Auk pess jukust heildarskuldirnar vegna lána í tengslum við efnahagsáætlun stjórnvalda og AGS og vegna endurfjármögnunar bankanna, sérstaklega Landsbankans. Síðastnefndu tveir liðirnir hafa pó fyrst og fremst áhrif á vergar skuldir en ekki hreina peningalega eign vegna pess að eignir koma á móti skuldum. Sjá

${ }^{15}$ Staðan á fyrirsjáanlega eftir að versna eitthvað frá pví sem hún var árið 2009 áđur en hún batnar aftur. Par skiptir m.a. máli væntur hallarekstur hins opinbera árin 2010 og 2011. Líklegt er að hrein peningaleg staða nái lágmarki í ríflega $-50 \%$ af landsframleiðslu m.v. pær áætlanir sem nú eru uppi. 


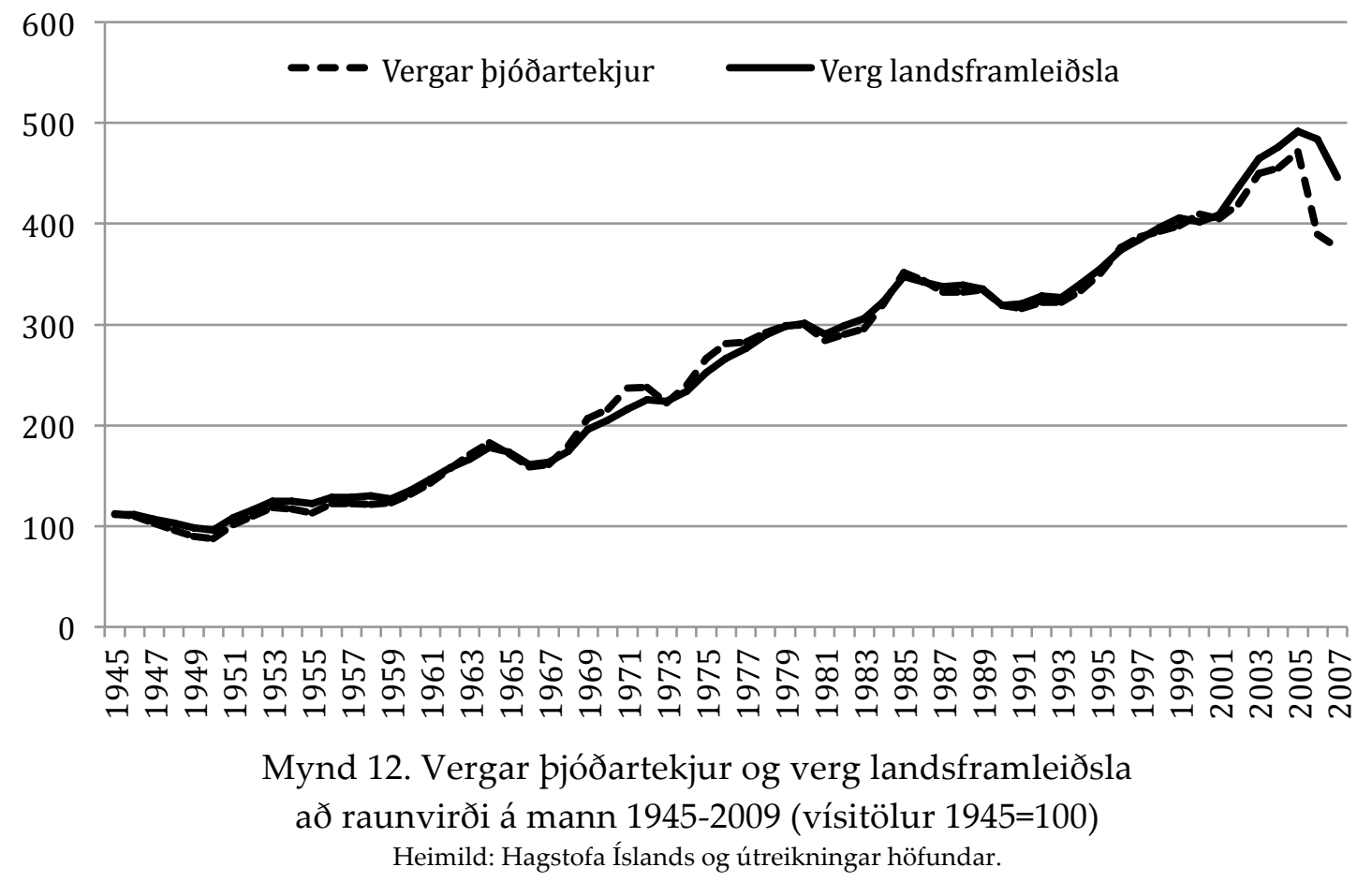

nánar mynd 11.

Í grófum dráttum tapaði hið opinbera við hrun fjármálakerfisins pví aftur sem uppgangurinn hafði skilað. Skiptingin á milli ríkis og sveitarfélaga flækir pó málið aðeins og sérstaklega раð аð nokkur sveitarfélög koma mjög illa út, m.a. vegna mikilla fjárfestinga og skuldsetningar í erlendri mynt sem pau eiga í erfiðleikum með að standa undir. Heildartölurnar fyrir hið opinbera segja pví ekki alla söguna.

\section{Niðurstaða og umfjöllun}

Pótt ekki sé búið að gera upp íslenska bóluhagkerfið er myndin smám saman að koma í ljós. Рað sem helst kann að koma á óvart við pá mynd er hve fjárhagslegt tjón pjóðarbúsins sem heildar er lítið. Raunar sýna tölurnar hér að framan að pjóðarbúið í heild átti í árslok 2009 umtalsvert meiri mannvirki og mannauð en í lok ársins 2002 og hrein peningaleg staða pess gagnvart útlöndum var svipuð. Раð er með ólíkindum í ljósi pess hve mikil neysla landsmanna var á árunum 2003 til 2007.

Tjónið vegna bóluhagkerfisins er engu að síður mjög raunverulegt en pað lendir að uppistöðu til á erlendum lánardrottnum hinna föllnu banka og útrásarfyrirtækjanna. Peir greiða pegar upp er staðið fyrir stóran hluta af íslensku neyslu- og fjárfestingarveislunni og að auki fyrir hagnað peirra ýmsu erlendu aðila sem seldu íslensku útrásarvíkingunum eignir. Endanlegur reikningur vegna pess liggur ekki fyrir en líklega verður hann á milli 3 og 4 púsund milljarðar. ${ }^{16}$

Meðaltöl eða heildartölur segja pó ekki nema hálfa söguna. Pótt íslenskt pjóðarbú komi

${ }^{16}$ Hafa má í huga að sumir peirra sem tapa sem kröfuhafar íslensku bankanna högnuðust áður, jafnvel verulega, á viðskiptum við íslenska bóluhagkerfið. Hreint tap slíkra aðila er pví ekki jafnmikið og pær kröfur sem afskrifa parf. Petta er hliðstætt við pá innlendu aðila sem högnuðust fyrst á eignaverðsbólunni en töpuðu síðan pegar hún hjaðnaði. 
sem heild furðu vel út, og par með meðal-Íslendingurinn, og hið opinbera á Íslandi komi nokkurn veginn út á sléttu fjárhagslega bera ýmsir innlendir hópar skarðan hlut frá borði.

Eignaverðsbólan raskaði mjög tekju- og eignaskiptingu á Íslandi, bæði meðan hún pandist út og pegar hún hjaðnaði. Peir sem koma illa út eru fyrst og fremst peir sem fjárfestu seint á eignamörkuðum og seldu ekki fyrir hrun. P.á m. peir sem keyptu sínar fyrstu íbúðir eftir 2004 og flestir peirra sem keyptu hlutabréf eða stofnfjárbréf á bólutímanum. Peir sem sátu uppi með vogaðar stöður eða stutt erlend lán pegar fjaraði undan fjármálakerfinu komu sérstaklega illa út. Pá kemur samdráttur á vinnumarkaði mjög misilla við fólk. Margir verða hans lítt varir, nema e.t.v. í tímabundnum samdrætti kaupmáttar, en aðrir verða illa úti og missa miklar tekjur vegna atvinnuleysis. Раð mun taka talsverðan tíma að vinna úr pessari stöðu og eins og pegar er orðið ljóst pá geta orðið um pað nokkrar deilur hvernig standa skal að málum.

Í ljósi pess að allir helstu framleiðslupættir hagkerfisins eru lítt eða ekkert skaddaðir prátt fyrir hrun fjármálakerfisins er framleiðslugeta pess meira eða minna öll til staðar. Раð verður pó vitaskuld að færa framleiðslupætti frá atvinnugreinum sem dragast saman, svo sem byggingariðnaði eða pjónustu við innflutning, til annarra atvinnugreina og gera ýmsar breytingar á opinbera geiranum í ljósi nýrrar stöðu. Slík aðlögun tekur alltaf tíma og pess er ekki að vænta að hún verði sérstaklega ánægjuleg, a.m.k. ekki framan af.

Ísland var fyrir hrun eitt allra ríkasta land í heimi á mælikvarða kaupmáttar, landsframleiðslu á mann og raunar einnig ef breiðari mælikvarðar eru notaðir. Раð er afrakstur gríðarlegs vaxtar meira eða minna alla 20. öldina eins og sjá má að hluta á mynd 12. Bakslagið nú færir landsmenn nokkur ár aftur í tímann á pennan mælikvarða, líklega til ársins 2004 ef kaupmáttur almennings er skoðaður en 2005 ef kaupmáttur landsframleiðslu er skoðaður. Рað er prátt fyrir allt mjög góð staða, bæði í sögulegu samhengi og alpjóðlegum samanburði. Ekki eru neinar efnahagslegar ástæður fyrir pví að ekki ætti að vera hægt að halda peirri stöðu að Ísland verði áfram eitt peirra landa heims sem búa pegnum sínum best lífskjör.

Við uppgjör sem petta er freistandi að velta pví fyrir sér hvort hægt hefði verið að breyta gangi máli til hins betra með öðrum ákvörðunum en peim sem í raun voru teknar. Írar tóku t.d. ákvörðun að bjarga sínu bankakerfi og hættu vegna pess gríðarlega miklu af fé hins opinbera. Íslendingar áttu ekki pennan valkost í raun en gældu pó við hann í aðdraganda hrunsins. Nú er of snemmt að segja til um pað hvor pjóðin mun á endanum koma betur út úr pessum hildarleik, p.e. hvort pað hefði verið affarasælla fyrir Íra að láta sína banka fara í prot, líkt og pá íslensku. Ljóst virðist a.m.k. að írska leiðin er miklu ódýrari fyrir lánardrottna bankakerfisins en sú sem Íslendingar neyddust til að fara pegar í óefni var komið.

Að lokum er rétt að hafa í huga að ýmis skaði getur orðið sem ekki kemur fram í hagtölum, a.m.k. ekki til skamms tíma. Félagslegir innviðir skipta ekki minna máli en margar efnahagsstærðir, bæði fyrir efnahagslífið sem slíkt og mannlíf almennt. Hafi peir skemmst illa í sviptingum undanfarinna ára getur verið að sá skaði verði ekki ljós að fullu fyrr en langt er um liðið. Раð sama má segja um orðspor Íslendinga í augum umheimsins. Рað hefur að ýmsu leyti beðið hnekki. Margir hafa tapað miklu á íslenska útrásarhagkerfinu og verða vart jafnfúsir til viðskipta við íslenska aðila í framtíðinni. Erfitt er að meta afleiðingar pess nú.

\section{Heimild}

Rannsóknarnefnd Alpingis. (2010). Aðdragandi og orsakir falls íslensku bankanna 2008 og tengdir atburðir. Reykjavík. 